\title{
A RESPONSABILIDADE CIVIL FRENTE AOS APLICATIVOS E-COMMERCE
}

Guilherme Machado Borges

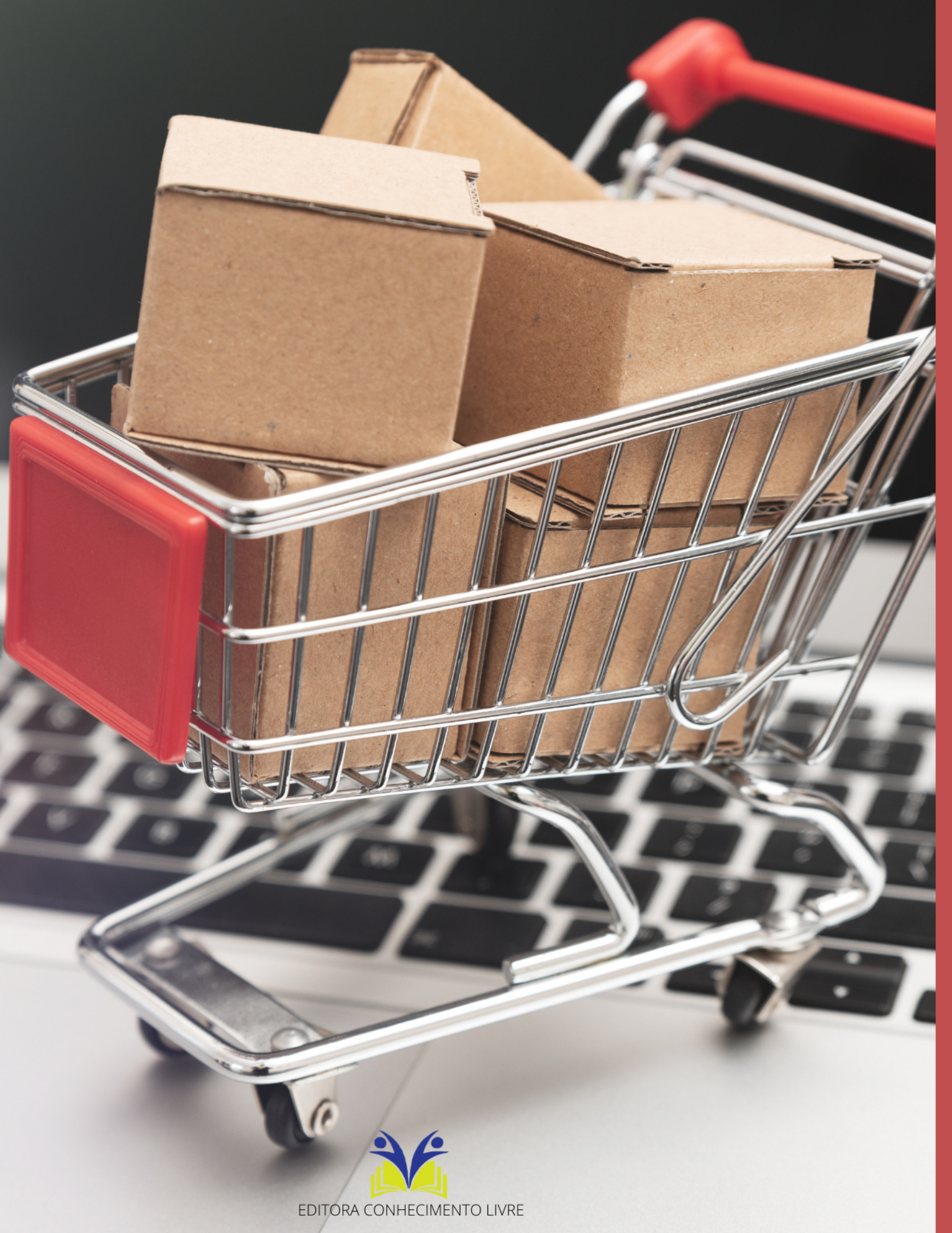


Guilherme Machado Borges

A RESPONSABILIDADE CIVIL FRENTE AOS APLICATIVOS E-COMMERCE

$1^{\text {a }}$ ed.

Piracanjuba-GO

Editora Conhecimento Livre

Piracanjuba-GO 
$1^{\mathrm{a}} \mathrm{ed}$

\section{Dados Internacionais de Catalogação na Publicação (CIP)}

Borges, Guilherme Machado
B955A AESPONSABILIDADE CIVIL FRENTE AOS APLICATIVOS E-COMMERCE
/ Guilherme Machado Borges. - Piracanjuba-GO
Editora Conhecimento Livre, 2021
53 f.: il
DOI: 10.37423/2021.edcl400
ISBN: 978-65-5367-020-4
Modo de acesso: World Wide Web
Incluir Bibliografia
1. responsabilidade 2. civil 3. aplicativos I. Borges, Guilherme Machado II. Título

https://doi.org/10.37423/2021.edc1400

O conteúdo dos artigos e sua correção ortográfica são de responsabilidade exclusiva dos seus respectivos autores. 


\title{
EDITORA CONHECIMENTO LIVRE
}

\section{Corpo Editorial}

\author{
Dr. João Luís Ribeiro Ulhôa \\ Dra. Eyde Cristianne Saraiva-Bonatto \\ MSc. Frederico Celestino Barbosa \\ MSc. Carlos Eduardo de Oliveira Gontijo \\ MSc. Plínio Ferreira Pires
}


A RESPONSABILIDADE CIVIL FRENTE AOS APLICATIVOS E-COMMERCE

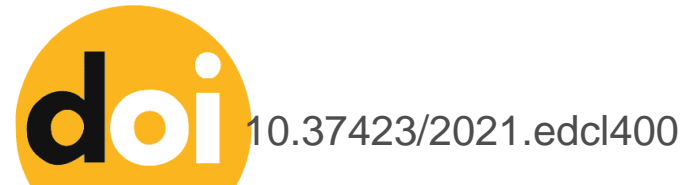

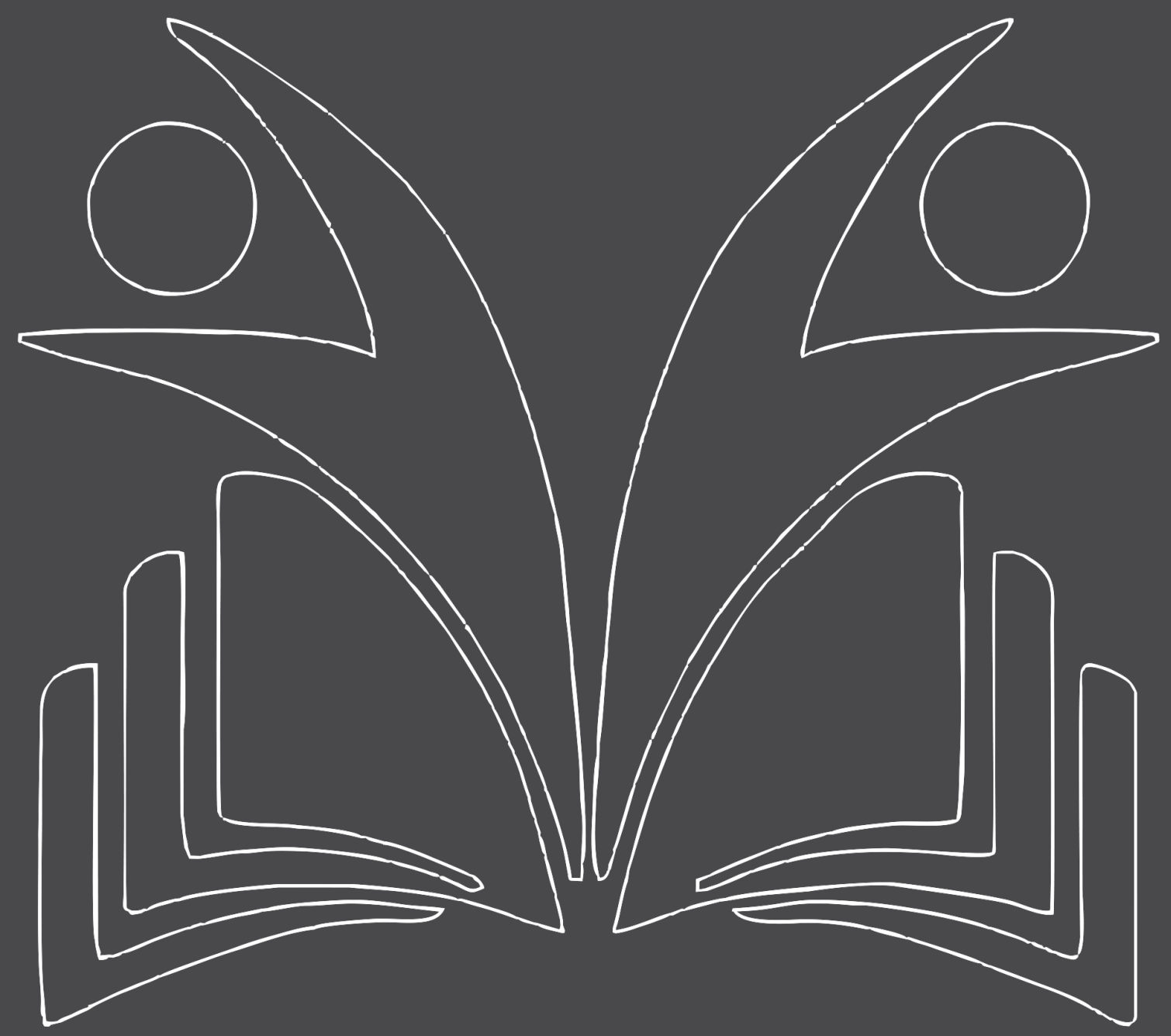




\section{A Responsabilidade Civil Frente Aos Aplicativos E-Commerce}

"O sucesso nasce do querer, da determinação e persistência em se chegar a um objetivo. Mesmo não atingindo o alvo, quem busca e vence obstáculos, no mínimo fará coisas admiráveis." José de Alencar 


\section{A Responsabilidade Civil Frente Aos Aplicativos E-Commerce}

Agradecer primeiramente a Deus e aos meus pais que sempre me incentivaram a buscar o conhecimento e nunca desistir dos meus sonhos. 


\section{A Responsabilidade Civil Frente Aos Aplicativos E-Commerce}

Resumo: $O$ presente trabalho de conclusão de curso tem como objetivo analisar a definição de responsabilidade civil, sua evolução histórica, bem como, sua aplicação dentro do ordenamento jurídico brasileiro a respeito das obrigações e responsabilidades de plataformas e aplicativos ecommerce. O método aplicado foi o dedutivo. Nesse formato, parte-se de uma constatação geral visando comprovar um argumento particular. Dessa forma, será utilizado a lógica para confirmar conhecimentos já definidos, não gerando novas afirmações. A grande problemática discutida é em relação a divergências que podem ocorrer entre o momento da contratação do serviço de e-commerce (realizar um pedido pelo aplicativo ou site) e sua entrega (faltando algo, atraso na entrega, entre outras possibilidades que causam dano no consumidor final). Durante a produção desta pesquisa foi entendido que a reparação do dano causado deve ser feita exclusivamente pelo causador do dano, mesmo que não exista um vínculo contratual pré acordado entre as duas partes (a contratante e a ofertante). Concluindo, então, que mesmo ao pedir um delivery sem um contrato efetivo a ofertante deve garantir a entrega e um padrão de qualidade e caso não ocorra, deverá haver uma atribuição de responsabilidade corretiva.

Palavras chave: Responsabilidade Civil. Prestador de Serviços. Consumidor. Delivery. Aplicativos de entrega. 


\section{A Responsabilidade Civil Frente Aos Aplicativos E-Commerce}

\section{Sumário}

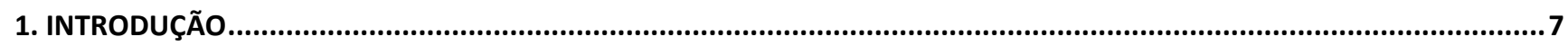

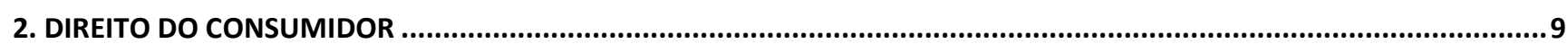

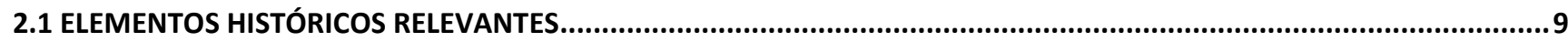

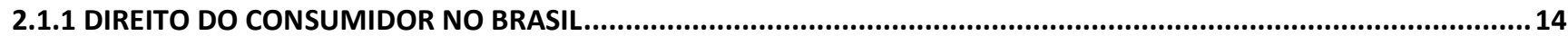

2.1.2 CONCEITOS

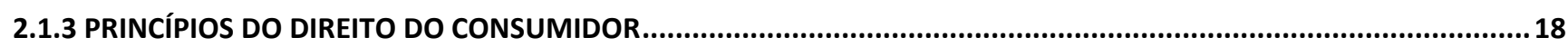

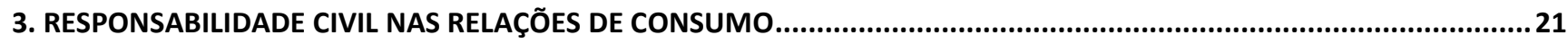

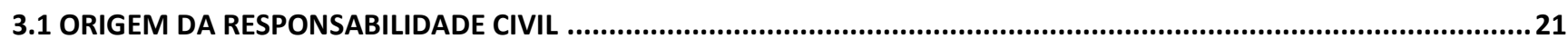

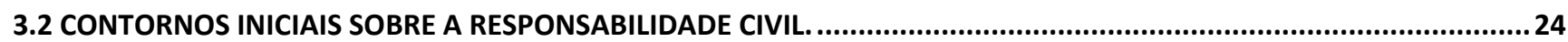

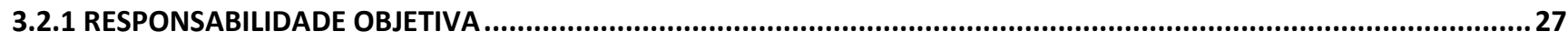

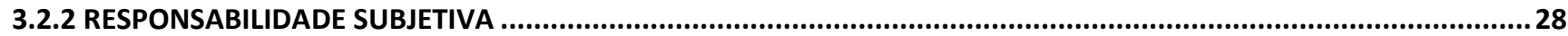

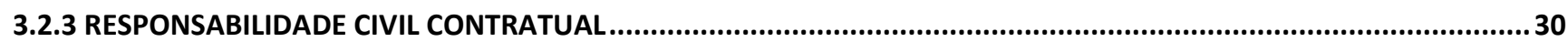

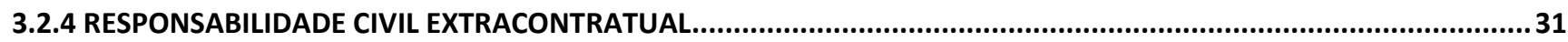

3.3 RESPONSABILIDADE CIVIL NAS RELAÇÕES DE CONSUMO

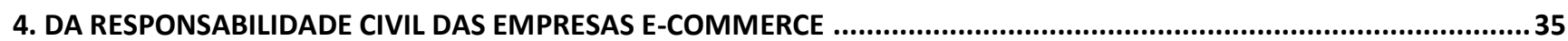

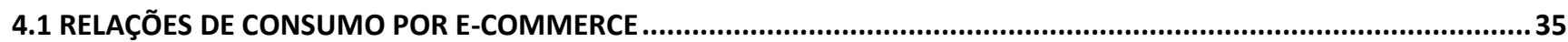

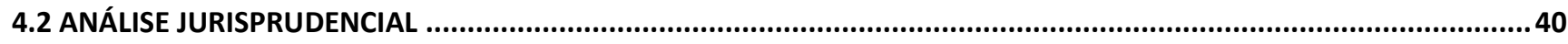

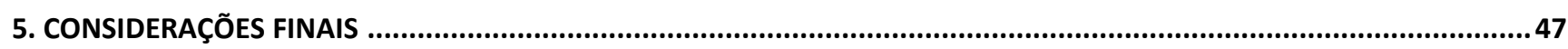

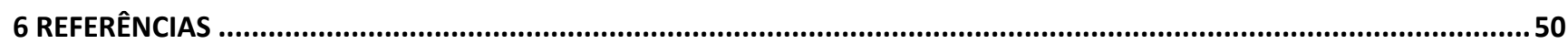




\section{A Responsabilidade Civil Frente Aos Aplicativos E-Commerce}

\section{INTRODUÇÃO}

A partir das relações de consumo via internet, nascem novos problemas como também surgem novas demandas por justiça, com ênfase no âmbito da defesa do consumidor, consumidor este que é atraído pelas facilidades que o consumo virtual oferece.

O presente trabalho aborda a temática da responsabilidade civil do prestador de serviços de plataformas e aplicativos de Delivery como Ifood, AiqFome, Uber Eats e Rappi na seara do direito do consumidor. A pesquisa é justificada em razão da grande quantidade de demandas que tramitam no Poder Judiciário envolvendo a responsabilidade civil dos prestadores de serviços com relação à causa de danos morais e materiais nas relações de consumo.

A aludida matéria encontra amparada pelo Código Civil e pelo Código de Defesa do Consumidor, que preveem quando um ato ilícito causa dano que deve ser reparado pelo causador, nos artigos 186 e 927 do Código Civil, e nos artigos do Código de Defesa do Consumidor que dizem respeito à prestação de serviços, ao fornecimento de produtos e à responsabilidade das pessoas que fazem parte da relação de consumo, bem como os casos em que não se pode responsabilizar o prestador de serviços, chamados de excludentes de responsabilidade.

A responsabilidade civil do prestador de serviços surgiu no direito consumerista com o objetivo de regular as relações de consumo e penalizar o causador da lesão pelos danos causados ao consumidor pelo defeito no produto ou pela má prestação do serviço. O legislador busca especificar os casos em que a responsabilidade provém de relação contratual ou extracontratual, quando é objetiva ou subjetiva, ou quando ela não ocorre, devido à ausência do nexo causal entre o dano e a conduta do agente.

Dessa forma, a pesquisa teve início com o questionamento sobre casos em que a entrega da comida pode ter tido alguma divergência do que foi acordado ou do que se é esperado ao contratar um serviço de entrega alimentício por aplicativo. A pesquisa apresenta como objetivo geral a análise da responsabilidade civil das plataformas de entrega (e seus aplicativos derivados desta) na ótica de quais são os limites e obrigações das partes envolvidas, tendo como foco principal a fornecedora do serviço no Código de Defesa do Consumidor. E, como objetivos específicos: identificar os pressupostos da responsabilidade civil; observar a evolução histórica da responsabilidade civil; analisar os tipos de responsabilidade civil no direito do consumidor. 


\section{A Responsabilidade Civil Frente Aos Aplicativos E-Commerce}

A pesquisa foi realizada através de consulta a doutrinas, jurisprudências e na legislação aplicável em vigor, as quais estão disponíveis em acervos públicos e privados, inclusive em meio digital. Para desenvolver o tema, no primeiro capítulo será feito um estudo acerca da evolução histórica da responsabilidade civil e sua definição, diferenciando-a da responsabilidade penal. Posteriormente no segundo capítulo se analisa a responsabilidade civil no direito brasileiro, apontando suas modalidades, que são objetiva e subjetiva, contratual e extracontratual. Por fim, no terceiro capítulo aborda-se a questão específica, o objetivo do presente trabalho, que é a responsabilidade civil dos prestadores de serviço no direito do consumidor, através de análise da doutrina e jurisprudência acerca do tema.

A metodologia para produção deste trabalho envolve pesquisa, haja vista que é através desta que se torna possível chegar a uma conclusão sobre o tema do qual o presente é fruto.

Segundo Gil (2007, p. 17) a pesquisa é um "procedimento racional e sistemático que tem como objetivo proporcionar respostas aos problemas que são propostos". Nesse viés, este estudo caracteriza-se como uma pesquisa exploratória com abordagem qualitativa, resultando, ainda, na abordagem de pesquisa bibliográfica.

Prevalece no presente trabalho o método dedutivo, o qual parte de constatações gerais, visando chegar a uma conclusão particular, que será considerada verdadeira, conforme ratifica Gil (2008, p. 9) "parte de princípios reconhecidos como verdadeiros e indiscutíveis e possibilita chegar a conclusões de maneira puramente formal, isto é, em virtude unicamente de sua lógica".

Deste modo, a pretensão é interpretar conhecimentos já existentes, e não de originar novos conhecimentos.

Por se tratar de assunto relevante e atual, se torna viável a realização deste trabalho, tendo em vista que o tema tem sido abordado em doutrinas, artigos e jurisprudências, o que propicia a fundamentação desta pesquisa. No primeiro capítulo, visa-se conhecer direito do consumidor e os elementos históricos relevantes seguindo sobre a Responsabilidade civil nas relações de consumo e das Medidas protetivas de urgência. No segundo capítulo será ressaltado a origem da responsabilidade, bem como suas tipologias, e para finalizar no terceiro capítulo será mencionada algumas jurisprudências a respeito do tema. 


\section{A Responsabilidade Civil Frente Aos Aplicativos E-Commerce}

\section{DIREITO DO CONSUMIDOR}

O capítulo a diante tratara do direito do consumidor, abordando seus aspectos históricos mais relevantes, bem como explanar sobre como esse direito funciona no Brasil, buscou-se também versar sobre os conceitos e citar seus principais princípios.

\subsection{ELEMENTOS HISTÓRICOS RELEVANTES}

A relação de consumo entre pessoas é um dos mais antigos meios de sobrevivência, visto que, desde muito antes do nascimento do cristianismo, já havia relações de troca de alimentos entre pessoas, quase sempre nômades, trocavam parte do seu alimento, proveniente de plantações ou de caça, por outros produtos do qual necessitava. (SPRÉA, 2015)

Cronologicamente pode-se citar o Código de Hamurabi (2.300 a.C.) que já regulava as relações de comércio como um todo e procurou o controle e a supervisão daquelas relações, condicionadas às atividades mais comuns da época. Pela importância que essa tarefa tinha então, o Código de Hamurabi determinava que o artesão construtor de barcos refizesse, às suas expensas, o trabalho considerado defeituoso. (HOTLHAUSEN, 2006)

O Código de Hamurabi é um conjunto de leis criadas na Mesopotâmia por volta do século XVIII a.C, pelo rei Hamurabi da primeira dinastia babilônica. O código é baseado na lei de talião, "olho por olho, dente por dente". (HOTLHAUSEN, 2006)

Visto como a mais fiel origem do Direito. É a legislação mais antiga de que se tem conhecimento, e o seu trecho mais conhecido é chamada lei de talião. Ele é pequeno, tendo em seu original três mil e seiscentas linhas, sendo essas linhas ordenadas em duzentos e oitenta e dois artigos, sendo que de alguns deles não há conhecimento completo de sua redação. (SPREA, 2015).

A esse respeito, Hotlhausen (2006, p. 44) menciona que:

O Código de Hamurabi tem-se convencionado pelos doutrinadores como a primeira legislação a tutelar 0 adquirente por problemas nos produtos/serviços". O mesmo autor, na mesma obra, refere a Lei das XII Tábuas, que determinava que "se alguém coloca o seu dinheiro a juros superiores a um por cento, que seja condenado a devolver o quádruplo.

Rollemberg (1987 apud FILOMENO, 1991, p. 45) norteia que:

Há quem denote já no antigo Código de Hamurabi certas regras que, ainda que indiretamente, visavam proteger o consumidor. Assim, por exemplo, a Lei 233 rezava que o arquiteto que viesse a construir uma casa cujas paredes se 


\section{A Responsabilidade Civil Frente Aos Aplicativos E-Commerce}

revelassem deficientes, teria a obrigação de reconstruí-las ou consolidá-las às suas próprias expensas.

No século XIII antes de Cristo, o Código sagrado de Manu delineava multa, punição e ou ressarcimento de danos para o indivíduo que adulterasse gêneros, ou entregassem coisa inferior daquela previamente acertada, ou vendessem bens de mesma natureza para pessoas diferentes por valores diferentes. (MOURA, 2012)

De acordo com Moura (2012), o Código de Manu foi escrito aproximadamente no ano 1000 a. C., é a legislação mais antiga da Índia. Os hindus possuíam quatro livros sagrados, denominados "Livros Sagrados dos Vedas", sendo que desses, o Código de Manu era o mais antigo, dividindo-se em Religião, Moral e Leis Civis. A aplicação do direito dizia respeito à casta do sujeito, a sua condição social.

Na Roma Antiga, o Direito Romano já previa proteção ao consumidor, quando estabelecia que o vendedor era responsável pelos vícios da coisa, a menos que ele não os conhecesse. Essa obrigação, no período Justiniano, foi até ampliada, sendo responsáveis mesmo se desconhecessem tal vício. Se o vendedor agisse de má-fé, tendo ciência do defeito, haveria de devolver em dobro o valor pago. Roma, através de várias leis, exercia a intervenção do

Estado no exercício do comércio, onde regras de consumo eram estabelecidas, como as práticas de controle de abastecimento de produtos. (BIBLIOTECA DA HISTÓRIA UNIVERSAL,

ROMA IMPERIAL, 1969 apud SENNA, 2009).

Na Grécia antiga, por sua vez, a Constituição de Atenas, escrita por Aristóteles, trazia grande preocupação com a defesa do consumidor. Como ensina (ARISTÓTELES, 1995, p. 103- 105 apud SENNA, 2009):

[...] são também designados por sorteio os fiscais de mercado, cinco para o Pireu e cinco para a cidade. As leis atribuem-lhes os encargos atinentes às mercadorias em geral, a fim de que os produtos vendidos não contenham misturas nem sejam adulterados; são também designados por sorteio os fiscais das medidas, cinco para a cidade e cinco para o Pireu; ficam o seu encargo as medidas e os pesos em geral a fim de que os vendedores utilizem os corretos. Havia também os guardiões de trigo; eles se encarregavam em primeiro lugar, de que o trigo em grão colocado no mercado seja vendido honestamente; depois, de que os moleiros vendam a farinha por um preço correspondente ao do trigo e com o seu peso na medida por eles prescrita (com efeito, a lei ordena que eles o fixem); são também designados por sorteio dez inspetores do comércio, aos quais se atribuem os encargos mercantis, devendo eles obrigar os comerciantes a trazerem para a cidade dois terços do trigo transportados para comercialização (...) o juro de uma dracma incidente sobre o capital de uma mina implicava taxa de $1 \%$ ao mês ou $12 \%$ ao ano. 


\section{A Responsabilidade Civil Frente Aos Aplicativos E-Commerce}

Spréa (2015) manifesta que Cícero sempre chamava atenção nas causas que defendia, para assegurar para o adquirente de bens de consumo a garantia das defasagens ocultas, nas relações de compra e venda, teriam solução ou em caso de impossibilidade, haveria a chamada resilição contratual (cláusula ex rempto). Tal circunstância, como sabemos, consagrou-se a tempos no direito pátrio sob o nome de "vícios redibitórios".

Quanto a Idade Média, iniciada historicamente com a queda do Império Romano, apresenta no mesmo contexto diversas influências e variações no direito, o que não houve grandes mudanças do direito romano clássico para o direito medieval, uma vez que se manteve a característica de imobilidade social e a massa trabalhadora submetia-se ao regime de servidão coletiva, não havendo necessidade de codificação. (BLOCH, 1989)

No tocante à sociedade, no regime do feudalismo, que se localiza o cerne das relações de consumo. $O$ sistema feudal caracteriza-se basicamente pelo poder centralizado do estado, pelo domínio social, político e econômico da classe nobre nos feudos com destaque para a figura dos senhores feudais que possuíam sua economia baseada na agricultura; servidão coletiva representada pelos vassalos e, a forte influência da igreja sobre as decisões polít icas e a própria vida dos indivíduos. (MENDONÇA, 2019)

Na França de Luiz XI, corrente o ano de 1481, punia com banho escaldante aquele que vendesse manteiga com pedra oculta para aumentar o peso ou misturasse água no leite (BIBLIOTECA DA HISTÓRIA UNIVERSAL, Europa, 1969). No ano de 1773, aconteceu nos Estados Unidos o episódio contra o imposto do chá, reação dos consumidores contra os produtores do chá inglês, quando colonos americanos, vestidos como nativos, destruíram a carga de chá. (BIBLIOTECA DA HISTÓRIA UNIVERSAL, América, 1969 apud SENNA,

2009). Na Suécia, a primeira legislação de proteção ao consumidor surge em 1910. (BIBLIOTECA DA HISTÓRIA UNIVERSAL, Europa, 1969 apud SENNA, 2009).

Em 1914, nos EUA criou-se a Federal Trade Comission, ou Comissão Federal de Comércio, que tinha o objetivo de aplicar a lei antitruste e proteger os interesses do consumidor. (Biblioteca da História Universal, América, 1969).

Spréa (2015), explica que um pouco mais tarde, no ano de 1936, era fundada a Consumers Union Of The United States, sendo uma entidade com as mesmas características da primeira, mas com algumas modificações, passando a também informar o consumidor de real situação do mercado e a relação 


\section{A Responsabilidade Civil Frente Aos Aplicativos E-Commerce}

custo benefício de cada produto. Toca salientar que tal órgão passou a ser o maior daquela época. Dois anos após, uma das principais modificações do movimento veio à tona, a publicidade enganosa se tornou proibida para determinados produtos.

Desde o final da Segunda Grande Guerra (1939-1945), sempre se buscou entender os problemas inerentes à produção de bens, à prestação de serviços e ao consumo, tendo em vista a Grande Depressão Econômica, originada com a Queda da Bolsa de Valores de Nova lorque, em 1929, a qual pôs fim ao Liberalismo na Economia. A Guerra Fria acirrou tanto a disputa ideológica, política, quanto à luta por mercados, levando os países a se preocuparem com a corrida armamentista e com a possível pletora geral na Economia.

O Direito do Consumidor tem origem nas sociedades capitalistas centrais (EUA, Inglaterra, Alemanha e França), sendo que as primeiras legislações protetivas dos direitos dos consumidores surgiram nos EUA, com o pronunciamento de John Kennedy ao Congresso norte americano em 1962. Kennedy localizou os aspectos mais importantes na questão de proteção ao consumidor, que iriam desde que os bens e serviços deviam ser seguros para uso ao direito a preços justos. Dizem alguns autores e noticiaristas que esse pronunciamento teve influência direta da então primeira-dama americana. (BIBLIOTECA DA HISTÓRIA UNIVERSAL, América, 1969).

[...] no dia 15 de março de 1962, o então presidente dos Estados Unidos, John Kennedy, enviou uma mensagem ao Congresso Americano tratando da proteção dos interesses e direitos dos consumidores. "Consumidores somos todos nós", disse ele nessa fala que se tornou o marco fundamental do nascimento dos chamados direitos dos consumidores e que causou grande impacto nos EUA e no resto do mundo. Na mensagem, foram estabelecidos quatro pontos básicos de garantia aos consumidores: o do direito à segurança ou proteção contra a comercialização de produtos perigosos à saúde e à vida; o do direito à informação, incluindo os aspectos gerais da propaganda e o da obrigatoriedade do fornecimento de informações sobre os produtos e sua utilização; o do direito à opção, no combate aos monopólios e oligopólios e na defesa da concorrência e da competitividade como fatores favoráveis ao consumidor; e o do direito a ser ouvido na elaboração das políticas públicas que sejam de seu interesse. (NUNES, 2013, p. 347)

As origens da preocupação com os direitos dos consumidores são tradicionalmente indicadas ao conhecido discurso, nos Estados Unidos, do Presidente John F. Kennedy no Congresso ao enunciar a necessidade de proteção do consumidor, referiu como direitos básicos o direito à segurança, o direito à informação, o direito de escolha e o direito a ser ouvido. Diante desse discurso, foi proposta a 


\section{A Responsabilidade Civil Frente Aos Aplicativos E-Commerce}

resolução no 248 da 39ạ Assembleia Geral da Organização das Nações Unidas (ONU), ratificada no 106을 Encontro Plenário, aos 9 de abril de 1985, a qual estabelece os:

Direitos fundamentais dos consumidores, direitos esses universais e indisponíveis, fazendo eco, aliás, com a própria doutrina dos direitos humanos. Como princípios gerais, diz o item 2 da referida Resolução ONU no 39/248 que 'os governos devem desenvolver, reforçar ou manter uma política firme de proteção ao consumidor, considerando as normas abaixo discriminadas', acrescentando ainda que, ao fazê-lo, 'cada governo deve determinar suas próprias prioridades para a proteção dos consumidores, de acordo com as circunstâncias econômicas e sociais do país e as necessidades de sua população, verificando os custos e benefícios das medidas propostas'. É no item 3 que se encontra a síntese das normas de proteção a que alude o de no 2, a saber: '3. As normas servirão para atingir as seguintes necessidades: a) proteger 0 consumidor quanto a prejuízos à saúde e segurança; b) fomentar e proteger o interesse econômico dos consumidores; c) fornecer aos consumidores informações adequadas para capacitá-los a fazer escolhas de acordo com as necessidades e desejos individuais; d) educar o consumidor; e) criar possibilidade de real ressarcimento ao consumidor; f) garantir a liberdade para formar grupos de consumidores e outros grupos ou organizações de relevância e oportunidades para que estas organizações possam apresentar seus enfoques nos processos decisórios a ela referentes (GRINOVER, 2004, p. 133-134).

Concomitantemente, ao que ocorria nos EUA, por volta da década de cinquenta, influenciados pelos norte-americanos, o movimento consumerista começa a surgir de forma tímida em alguns países europeus. Os primeiros países a se renderem ao movimento foram a França e a Alemanha, onde foram criadas cúpulas para aconselhar consumidores. (SPRÉA, 2015).

Na década de sessenta algumas instituições internacionais viram a necessidade de adesão a Federação das Nações dos Consumidores, criando a Internacional Office of Consumers Unions (IOCU), em Haia e a Bureau Européen des Unions Consommateurs (BEUC) em Bruxelas. Nos anos setenta e oitenta os grandes marcos foram a Carta De Proteção do Consumidor do Conselho da Europa, influenciada pelos EUA, e os programas da Comunidade Econômica Europeia para uma nova política de assistência ao consumidor. (SPRÉA, 2015).

Em decorrência, em abril de 1975, o Conselho da Comunidade Europeia redige resolução na qual descreve os direitos fundamentais do consumidor através da seguinte divisão: (i) o direito à proteção da saúde e da segurança, (ii) o direito à proteção dos interesses econômicos, (iii) o direito à reparação dos prejuízos, (iv) o direito à informação e à educação e (v) o direito à representação (CAVALIERI FILHO, 2009). Nesse contexto, observa-se um crescente processo de elaboração de leis objetivando a proteção do consumidor. De modo a visualizar o verdadeiro movimento de codificação, tomam-se os 


\section{A Responsabilidade Civil Frente Aos Aplicativos E-Commerce}

exemplos de França, Espanha e Portugal, escolha em razão da influência que perfizeram no Código de Defesa do Consumidor brasileiro.

Spréa (2015), expende que em 2000, ocorreu a publicação da Carta dos Direitos Fundamentais da União Europeia. Finalmente, afastando-se do contexto europeu e passando a uma visão internacional, foram criados os Programas da Organização das Nações Unidas.

Faz-se importante a explanação dessa trajetória, visto que, se não fosse esses acontecimentos históricos, a efetivação de tal ramo do direito poderia se alongar por muito mais tempo, visto que foram esses os pontos chaves para a luta, mais adiante, da efetivação dos direitos do consumidor.

\subsubsection{DIREITO DO CONSUMIDOR NO BRASIL}

Giordano Bruno Soares Roberto (2003) explana que não é possível compreender o momento atual do Direito Privado brasileiro sem olhar para sua história. Para tanto, não será suficiente começar com o desembarque das caravelas portuguesas em 1500. A história é mais antiga. O Direito brasileiro é filho do Direito Português que, a seu turno, participa de um contexto mais amplo.

O direito pátrio, durante o período de colonização, era resumido ao que era imposto pelo Reino de Portugal, ou seja, nossos direitos civis eram simples extensão dos portugueses.

Observava-se uma proteção discreta do consumidor. No Livro V das Ordenações Filipinas encontramse normas de proteção ao consumidor. O título LVII diz que "se alguma pessoa falsificar alguma mercadoria, assim com cera, ou outra qualquer, se a falsidade, que nisso fizer, valer hum marco de prata, morra por isso". (QUINTO LIVRO, 2009).

No período colonial havia multas para quem vendesse mercadorias acima das tabelas fixadas. Assim, também, aos taberneiros que vendessem vinho acima do preço tabelado. E havia limitação ao número de tabernas, fixadas em máximo de doze, em Salvador, por exemplo. Por conta da grande demanda de vinho, era comum os taberneiros inflacionar o mercado. E, após muitas queixas da população, a Câmara decidiu punir severamente os infratores. Assim, quem vendesse o canada (medida da época equivalente a 1,4 litros) acima de 2 cruzados (800 réis), seria preso na envoxia (a pior cela da cidade) e dela levado para ser açoitado pelas ruas, ficaria inábil para vender e seria desterrado da capitania para todo o sempre. (ORDENAÇÕES FILIPINAS, 1957 apud SENNA, 2009).

Mas a real necessidade pátria da proteção ao consumidor emergiu nos anos cinquenta, mas seu real crescimento se deu na década de setenta e seu ápice no final da década de oitenta e início da década 


\section{A Responsabilidade Civil Frente Aos Aplicativos E-Commerce}

de noventa. Mas o inverso do ocorrido na América do Norte e nos países europeus essa necessidade não surgiu com o apelo da sociedade, mas sim sendo reivindicada por alguns doutrinadores e legisladores constituintes da época. (SPRÉA, 2015)

Na década de 1970, o cenário brasileiro da época, de um país de capitalismo periférico e dependente é de aumento da produção industrial, que passa a ser mais massificada. O que contribui também para o desenvolvimento do nível de consumo o aumento populacional e aumento das zonas urbanas.

Nesse período há o chamado "milagre econômico", com a expansão da indústria nacional por meio do endividamento brasileiro com empréstimos estrangeiros e também controle dos salários, havendo preocupação com o preço das mercadorias.

Entre 1968 e 1974, o Brasil cresceu como nunca antes em sua história e se torna a oitava maior economia do mundo, graças ao que se chamou de "milagre brasileiro". Durante esse período, tendo como base a expansão da indústria, das exportações, do emprego e do mercado interno, além de vultosos empréstimos externos, o Produto Interno Bruto (PIB) cresce em média $10 \%$ ao ano. Ao mesmo tempo, através de medidas de controle da moeda, dos salários - que ficou conhecido como "arrocho salarial" - e dos preços dos produtos industrializados, a inflação, anteriormente descontrolada, é mantida estável em torno de 20\%. (CÂMARA DOS DEPUTADOS, s.d.)

Ainda na década de 1970 foi criada a Associação de Defesa do Consumidor na cidade de Porto Alegre, Rio Grande do Sul. Em 1978 foi criado o Procon de São Paulo, por meio da Lei Estadual 1.903 de 1978, e na década de 1980, mais precisamente no ano de 1983 foi criado o Movimento de Donas de Casa de Minas Gerais (MCDG, 2017). Porém, em 1985 foi criado o Conselho Nacional de Defesa do Consumidor por meio do Decreto n. 91.469, com o objetivo de defesa específica do Consumidor (ALCARÁ, 2013).

A necessidade de regulação de tais relações também foi objeto da Resolução n. 39/248 de 16 de abril de 1985, a Organização das Nações Unidas que propunha aos países a proteção adequada aos consumidores, com políticas de defesa do consumidor (ALCARÁ, 2013).

Maia (2020), permeia que em 1987 foi criado o IDEC - Instituto Brasileiro de Defesa do Consumidor (IDEC 2012) que teve participação ativa na Assembleia Nacional Constituinte de 1987, pleiteando a inclusão do direito do Consumidor na Constituição Federal.

Assim, a proteção do consumidor no Brasil ganha importância inédita com a Constituição Federal de 1988, que consagrou a proteção do consumidor como garantia constitucional e como princípio norteador da atividade econômica. Embora o Código seja recente, o movimento de defesa do 


\section{A Responsabilidade Civil Frente Aos Aplicativos E-Commerce}

consumidor teve início com o pioneiro Projeto de Lei no.70, de 1971, do Deputado Nina Ribeiro Arena, que criou o Conselho de Defesa do Consumidor. (BRASIL, Constituição Federal de 1988).

Nesse cenário histórico, foi a Constituição brasileira com maior participação popular, já que a Constituinte de 1987 aceitava propostas encaminhadas pela população, as emendas populares (CASTRO, 2013).

Assim tiveram início os trabalhos de elaboração de um código nacional do consumidor, afinal coroados de êxito com a sanção da Lei no 8.078, aos 11 de setembro de 1990: o Código Brasileiro de Defesa do Consumidor, obra pioneira do Ordenamento Jurídico Brasileiro e exemplo para muitas legislações em várias partes do mundo.

Pelo que se pode observar, por conseguinte, trata-se de uma lei de cunho inter e multidisciplinar, além de ter o caráter de um verdadeiro microssistema jurídico. Ou seja: ao lado dos princípios que Ihe são próprios, no âmbito da chamada ciência consumerista, o Código Brasileiro do Consumidor relaciona-se com outros ramos do Direito, ao mesmo tempo em que atualiza e dá nova roupagem a antigos institutos jurídicos (GRINOVER, 2004, p. 19-20).

A proposta original de proteção ao consumidor apresentada à Constituinte era mais ampla, com a previsão de um capítulo específico para a defesa do consumidor (IDEC, 2012).

Todavia, apesar de não existir um capítulo próprio para a defesa do consumidor, não se pode diminuir a importância da conquista da inclusão de tal defesa ao patamar constitucional.

Aqui importa, então, anotar que o legislador constitucional inseriu no contexto das garantias do artigo 50 a defesa do consumidor como dever do Estado. 0 consumidor foi erigido ao posto de figura constitucional, exatamente porque numa sociedade capitalista como a nossa, inserida no contexto histórico do capitalismo moderno, passa a ser dever do Estado sua proteção. (NUNES, 2013, p. 348).

Spréa (2015), sanciona que mesmo ainda tardio, sendo somente sancionado em setembro de 1990, o atual Código de Defesa do Consumidor Pátrio, sob o nㅇ 8.078/90. Passando a vigorar em março de 1991, tinha a finalidade garantir os direitos dos consumidores nas relações de consumo de acordo com a realidade da época, do mesmo modo também deveria reavaliar o que era delimitado pelo ordenamento jurídico clássico, se baseia na responsabilidade subjetiva e a disciplina dos vícios redibitórios. Era necessário também, visto a maior necessidade da falta de lei que garanta a proteção das vítimas contra a proliferação de acidentes de consumo resultantes do aumento das relações entre fornecedores e consumidores. 


\section{A Responsabilidade Civil Frente Aos Aplicativos E-Commerce}

Pode-se adiantar que hoje o consumidor brasileiro está legislativamente bem equipado, mas ainda se ressente de proteção efetiva, por falta de vontade política e de recursos técnicos e materiais. Mesmo assim, há que ser festejado o grande avanço experimentado nos últimos anos, que alçou o País, nessa área, e em termos legislativos pelo menos, ao nível das nações mais avançadas do Planeta. (ALMEIDA, 2003)

Com a edição do Código de Defesa do Consumidor, os direitos do consumidor foram se consolidando, através da criação do microssistema das relações de consumo e da inserção de novas normas e princípios jurídicos. (BRASIL, Ministério da Justiça, 2009).

\subsubsection{CONCEITOS}

Para Maia (2020), o consumo, de uma maneira geral, é necessário para suprir as necessidades básicas dos seres humanos, como comer, vestir, abrigar-se, proteger sua integridade física e psíquica, por meio da saúde e da educação, ter lazer e acesso à cultura e, em uma sociedade com economia de mercado, capitalista, tais bens necessários à sobrevivência dos seres humanos se tornam mercadorias.

Karl Marx, define consumo como:

O consumo dos produtos do trabalho humano (valores de uso) é a maneira pela qual os seres humanos se mantêm e se reproduzem como indivíduos e como indivíduos sociais, isto é, tanto no sentido físico e mental (como seres humanos com uma determinada personalidade), como num contexto sócio-histórico (como membros de uma formação social, num período histórico específico). No capitalismo, isto é, na produção generalizada de mercadorias ("economia de mercado"), o consumo assume essencialmente a forma de consumo de mercadorias. (MARX apud BOTTOMORE, 1988, p. 133).

O consumidor, conforme definido no Código (Lei 8.078/90), é qualquer pessoa física ou jurídica que adquire produtos ou serviços como destinatário final, ou seja, para consumo próprio e não para revenda. Assim, sempre que alguém comprar um imóvel, um carro, ou um brinquedo, sem intenção de revendê-lo é legalmente considerado consumidor. De outro lado, não é consumidor - estando, portanto, excluído da proteção da Lei 8.078/90 - a pessoa física ou jurídica que adquire determinada mercadoria para revenda ou como matéria prima de produção de outros bens. (BRASIL, Ministério da Justiça, 2009).

Sobre a sociedade de consumidores, Bauman alerta:

A característica mais proeminente da sociedade de consumidores - ainda que cuidadosamente disfarçada e encoberta - é a transformação dos consumidores em mercadorias; ou antes, sua dissolução no mar de mercadorias em que, para citar aquela que talvez seja a mais citada entre as muitas sugestões citáveis de Georg Simmel, os diferentes significados das coisas 'e portanto as próprias coisas, são vivenciadas como imateriais', aparecendo 'num tom uniformemente 
monótono e cinzento' - enquanto tudo 'flutua com igual gravidade específica na corrente constante do dinheiro'.

(BAUMAN, 2008)

\subsubsection{PRINCÍPIOS DO DIREITO DO CONSUMIDOR}

O direito do consumidor é norteado, como os demais ramos do direito, por princípios gerais e se entende que é aos princípios de direito natural que o legislador manda recorrer à lacuna da normatividade.

Princípios, de uma maneira geral, são as normas fundamentais que embasam a elaboração das leis. São fontes não-escritas, que refletem os conceitos primordiais à técnica legislativa e tem os papeis de complementar a aplicação do direito escrito e de contribuir de modo a se obter o desfecho mais justo possível.

Na seara do Direito Consumerista, orientam a aplicação e integração dos seus preceitos, regulando a relação entre fornecedor e consumidor. Flávio Tartuce e Daniel Amorim Assumpção Neves (2017) trazem alguns princípios constantes do CDC, sejam eles implícitos ou explícitos:

P. da Proteção: em nome das incolumidades física, psíquica e econômica, as normas do CDC não podem ser afastadas, mesmo que por acordo entre as partes, sendo nulas quaisquer cláusulas abusivas (art. 1ㅇ);

P. da Transparência: a tutela da informação, que visa a proporcionar ciência da situação e direcionando-o para um modo consciente e seguro quanto às informações da relação de consumo (art. 4ㅇ, caput; art. 60, III);

P. da Vulnerabilidade: haja visto a discrepância na entre a teoria e a prática quanto à aplicação das regras comerciais, presume-se o consumidor como parte 21 vulnerável na relação de consumo, pouco importando sua condição social ou financeira (art. 4ำ, I);

P. da Hipossuficiência: não diz respeito apenas a valores monetários, mas também à disparidade técnica - desconhecimento em relação ao produto ou serviço - ou informacional - não ter acesso ou não poder produzir uma prova fundamental para buscar seu direito (art. 60, VIII);

P. da Boa-fé objetiva: busca-se o justo equilíbrio na relação de consumo; boafé não apenas subjetiva, psicológica, mas objetiva, prática (art. 4으, III);

P. da Dimensão Coletiva o prestígio da proteção à coletividade, mesmo que o interesse coletivo tenha que prevalecer sobre o individual;

P. da Precaução: é um princípio implícito e tem o intuito de proteger o consumidor de riscos desconhecidos em produtos e serviços no mercado.

O princípio da proteção se encontra descrito dentro do artigo 6으, do CDC protegendo a incolumidade física, psíquica, ou econômica. Este princípio foi conquistado e consolidado através da constituição federal no artigo 5ㅇ, XXXII da CF. Já o princípio da transparência, baseado na boa fé, norteia que o 


\section{A Responsabilidade Civil Frente Aos Aplicativos E-Commerce}

fornecedor por estar em uma situação superiormente desigual ante o consumidor, obrigatoriamente devera sempre informar ao consumidor sobre os riscos referentes ao negócio.

O princípio da vulnerabilidade é a porta de entrada para o início das demais regulamentações. Constatada essa vulnerabilidade do consumidor, foi iniciado um movimento no âmbito internacional com o intuito de reequilibrar as relações entre consumidores, produtores e prestadores de serviços. No ano de 1985, a ONU, pela resolução 39/248, "baixou norma sobre a proteção do consumidor [...] reconhecendo expressamente 'que os consumidores se deparam com desequilíbrios em termos econômicos, níveis educacionais e poder aquisitivo'" (ALMEIDA, 2002, p.05).

Segundo Antônio Herman V. e Benjamin ao prefaciar o livro de Moraes (1999, p.10) ressalta que, o princípio da vulnerabilidade representa a peça fundamental no mosaico jurídico que denominamos Direito do Consumidor. É lícito até dizer que a vulnerabilidade é o ponto de partida de toda a Teoria Geral dessa nova disciplina jurídica [...] A compreensão do princípio, assim, é pressuposto para o correto conhecimento do Direito do consumidor e para a aplicação da lei, de qualquer lei, que se ponha a salvaguardar o consumidor.

Marques (2014, p. 322), observa a existência de quatro tipos de vulnerabilidade. São elas (i) a técnica, (ii) a jurídica ou científica, (iii) a fática e (iv) a informacional. Interessante o destaque atribuído a essa última modalidade, como questão básica. Tratando-se de vulnerabilidade técnica, o termo central consiste na profissionalidade. Com efeito, tem-se no caso do consumidor não profissional o entendimento de que a vulnerabilidade técnica é presumida, pois se refere essencialmente ao produto ou serviço em questão e suas especificidades. Isto é, por não conhecer os aspectos do objeto da relação à medida semelhante do fornecedor, vê-se o consumidor como suscetível a ser ludibriado ou induzido.

O caso da vulnerabilidade jurídica ou científica, por sua vez, envolve a ausência de conhecimento, pelo consumidor, de elementos de contabilidade, direito e economia, relevantes, sobretudo, no que tange ao instrumento de vinculação - contratação de obrigações.

A partir dessa presunção, Marques comenta acerca de seu caráter irradiador de deveres de informação. O raciocínio consiste na ideia de que, sendo o consumidor não profissional presumidamente não conhecedor, e, ao mesmo tempo, o fornecedor, profissional, este possui o dever de esclarecimento frente ao contratante leigo. 


\section{A Responsabilidade Civil Frente Aos Aplicativos E-Commerce}

Marques ainda observa a vulnerabilidade fática, também denominada de socioeconômica. Nesse caso, a ideia central consiste na concentração de poder - seja pelo largo poder econômico, ou pela essencialidade do serviço.

A vulnerabilidade foi tradicionalmente dividida nessas três espécies supracitadas.

Devido, porém, a alterações da própria sociedade globalizada, Marques entende que o consumidor experimenta, hoje, uma nova modalidade: a vulnerabilidade informacional.

Tamanha é a importância da consideração desse tipo de vulnerabilidade, que Marques (2014) comenta que "esta vulnerabilidade informativa não deixa, porém, de representar hoje o maior fator de desequilíbrio da relação vis-à-vis dos fornecedores, os quais, mais do experts, são os únicos verdadeiros detentores da informação."

No caso de Moraes (1999, p. 132), destacam-se a vulnerabilidade política ou legislativa, caracterizada pela baixa força de atuação dos consumidores ou de associações representativas junto ao poder legislativo e em combate ao lobby dos fornecedores empresários; a vulnerabilidade biológica ou psíquica, que compreende a ideia de que o avançadíssimo nível das técnicas de vendas e marketing disponível aos fornecedores para “... aflorar desejos, criar vontades, manipular manifestações de vontade e, assim, gerar indefinidas circunstâncias que poderão ter como resultado o maior consumo..."; e a vulnerabilidade ambiental, que se refere ao prejuízo ambiental a ser suportado pelo consumidor ao longo do tempo acarretado por imposições mercadológicas dos fornecedores.

Assim, é relevante observar os agentes e os objetos da relação de consumo na ótica do Código de Defesa do Consumidor e do princípio da vulnerabilidade do consumidor, nitidamente imbuído dos mandamentos constitucionais.

Também pode-se mencionar outros princípios que compõemo código:

Princípio da confiança: Deve ser inerente a uma relação comercial a confiança entre as partes.

Princípio da precaução: Está incluído no CDC de maneira implícita e seu objetivo é preservar o consumidor de todos os vícios ou riscos desconhecidos.

Princípio da boa-fé objetiva: As partes sempre devem agir de maneira a buscar uma relação comercial leal, como descrito no artigo 4으, III, do Código de Defesa do

Consumidor. Sendo assim, segundo o artigo 51, IV, do CDC todas as cláusulas abusivas são nulas de pleno direito. 


\section{A Responsabilidade Civil Frente Aos Aplicativos E-Commerce}

Princípio da facilitação da Defesa: Diante da relação comercial desigual, uma das formas encontradas de se buscar a equidade das partes foi a inversão do ônus da prova sempre em benefício do consumidor.

Princípio da continuidade contratual: O consumidor deverá exigir que o valor ofertado ou anunciado de determinado serviço ou produto deverá ser o mesmo sem sofrer alterações.

Diante dos aspectos explicados, nota-se que o código visa estabelecer princípios básicos como proteção da vida, da saúde, da segurança e da educação relacionados ao consumo, tendo como objetivo determinar normas de proteção e defesa do consumidor, de ordem pública e interesse social.

\section{RESPONSABILIDADE CIVIL NAS RELAÇÕES DE CONSUMO}

O presente capítulo irá tratar da responsabilidade civil nas relações de consumo, iniciando pela sua origem histórica, trazendo seu conceito por renomados auutores e mencionar seus elementos estruturais.

\subsection{ORIGEM DA RESPONSABILIDADE CIVIL}

Jose Cairo Junior (2002) norteia que antes de existir uma sociedade organizada e mesmo nos primórdios dessa, prevalecia o princípio da vingança coletiva, ou seja, a ação ou omissão diante de uma situação provocava uma reação imediata e desmedida do ofendido, por meio de violência física ou moral não só ao ofensor, mas também a sua família, tribo ou grupo social.

Essa característica do Direito antigo onde não só a responsabilidade era coletiva, mas também a propriedade.

Não se sabe exatamente o momento histórico em que se originou a concepção de responsabilidade, tampouco, quando foi reconhecida juridicamente e praticada nos moldes da atualidade. No entanto, pode-se afirmar que desde o início da civilização sempre existiu ao menos a noção desse instituto, revelada, claramente, conforme a evolução social. (DINIZ, 2005, p. 10): Neste sentido, acrescenta-se: “A responsabilidade civil se relaciona profundamente com as formas de composição dos conflitos de interesses, pois presentes um dos reflexos da violação de um dever legal ou de uma obrigação criada por declaração de vontade". (CAIRO JÚNIOR, 2002).

Nunes e Ligero (2009, p.2), afirmam que nos primórdios da civilização humana, não se tinha a noção da responsabilidade civil como tentativa de restabelecimento do estado anterior ou como agente minimizador dos prejuízos causados por atos ilícitos e abusivos. A responsabilização era concretizada, 


\section{A Responsabilidade Civil Frente Aos Aplicativos E-Commerce}

na forma de vingança privada, com muita violência, sendo que as pessoas, para tanto, se valiam de sua posição social, religiosa e até mesmo intelectual.

Nunes e Ligero (2009, p. 6-7), pesquisaram que se passou a surgir à reparação dos danos nos casos específicos com alguns dos primeiros códigos, quais sejam, o Código de Manu, a Lei das XII Tábuas e o Código de Hamurabi que proporcionava a vítima uma lesão equivalente ao dano sofrido.

O Código de Hamurabi fazia referência em diversos parágrafos sobre a reparação pecuniária, ou seja, a reparação do dano pelo equivalente em dinheiro, mas ainda assim persistia a reparação do mal pelo mal. (NUNES E LIGERO, 2009, P. 6-7).

Gagliano e Pamplona Filho (2006, p.10) relatam sobre a predominância da vingança privada nas primeiras civilizações:

De fato, nas primeiras formas organizadas de sociedade, bem como nas civilizações pré-romanas, a origem do instituto está calcada na concepção de vingança privada, forma por certo rudimentar, mas compreensível do ponto de vista humano como lídima reação pessoal contra o mal sofrido.

Nunes e Ligero $(2009$, p.7) informam que com a Lei de Talião, surgindo uma reação contra aquele que causou um dano, era a chamada vingança privada, ou seja, uma reação natural e espontânea contra o dano. Havia a reparação do mal por outro mal, nesta época a sociedade fazia justiça com as próprias mãos, acreditavam que a resposta ao dano teria que ser na mesma proporção em que foi conferido.

Os homens faziam justiça com as próprias mãos, fundamentados na Lei de Talião, que é conhecida pelas expressões olho por olho, dente por dente, pagar na mesma moeda, quem com ferro fere com ferro será ferido, ou seja, o mal era reparado por outro mal (DINIZ, 2007).

A Lei das XII Tábuas, que segundo Júlio Bernardo do Carmo (1996, apud Cairo Júnior 2002) surgiu sob a égide de Terentilo Arsa, um tribuno do povo, após uma árdua luta de dez anos, (303/304 d.c), previa as hipóteses de composição obrigatória e voluntária.

No contexto da "Lei das Tábuas", Cairo Junior (2002), explica que o Estado percebeu que certos delitos, indiretamente, lhe atingiam e não só a vítima individualmente considerada, passou a não só definir a reparação, mas também executá-la. Com efeito, determinadas condutas ilícitas representavam uma subversão à ordem pública e não mera infração de direito privado, colocando em risco a própria existência da sociedade politicamente organizada.

Ao decorrer desse período surgiu a composição, diante da observância do fato de que seria mais conveniente o autor da ofensa reparar o dano mediante o pagamento de uma poena, ou seja, certa 


\section{A Responsabilidade Civil Frente Aos Aplicativos E-Commerce}

quantia em dinheiro. Sendo assim, a cobrança ficaria a critério da autoridade pública se o delito fosse público, ou do ofendido quando se tratasse de delito privado. A partir de então, as partes envolvidas concluíram que ao praticarem a retaliação não se reparava dano algum, pelo contrário causavam duplo dano: o da vítima e o de seu ofensor, depois de punido. (GAGLIANO; PAMPLONA FILHO, 2007, p.11)

Porém Nunes e Ligero (2009, p. 8), defendem que foi com a "Lex Aquília" que ficou pacificado o entendimento de que a reparação pelo agente provocador do prejuízo, deveria ser patrimonial, suportando o ônus de seus bens. Nasceu aqui também a responsabilidade extracontratual, em que a reparação deveria existir mesmo que não haja um vínculo preexistente entre as partes. A mais preciosa herança dessa lei é que a reparação do prejuízo passa a depender da culpa do agente causador do dano.

Neste sentido, acrescenta-se:

É na Lex Aquilia que se esboça, afinal, um princípio geral regulador do dano. Embora se reconheça que ainda não tinha uma regra de conjunto, nos moldes da relação à injúria, e "fonte direta da moderna concepção da culpa aquiliana, que tomou da Lei Aquilia o seu nome característico". (Gonçalves, 2003, p.4-5, apud, Nunes e Ligero, 2009)

Cretella Jr. (1986, p. 209, apud Cairo Junior, 2002), explica que a Lei Aquília foi o resultado de um plebiscito votado no final do quinto século, por iniciativa de um tribuno da plebe chamado Aquilio. Era uma lei circunstancial que beneficiava os plebeus, pois ficaram protegidos contra os prejuízos causados pelos patrícios nos limites de sua propriedade.

Sobre a introdução da Lex Aquília, Diniz (2007, p.11) aduz:

A Lex Aquilia de damno veio a cristalizar a ideia de reparação pecuniária do dano, impondo que o patrimônio do lesante suportasse os ônus da reparação, em razão do valor da res, esboçando-se a noção de culpa como fundamento da responsabilidade, de tal sorte que o agente se isentaria de qualquer responsabilidade se tivesse procedido sem culpa. Passou-se a atribuir o dano à conduta culposa do agente. A Lex Aquília de damno estabeleceu as bases da responsabilidade extracontratual, criando uma forma pecuniária de indenização do prejuízo, com base no estabelecimento de seu valor.

O conceito da "Lex Aquília" foi ampliado com o advento do Código de Napoleão, de 1804, aperfeiçoamse as ideias romanas, estabelecendo-se princípios gerais de responsabilidade, separando a responsabilidade civil, que era reparada perante a vítima, da responsabilidade penal, em que o autor, causando dano à sociedade respondia perante o Estado pelos ilícitos praticados. (GONÇALVES, 2003, p. 5). 


\section{A Responsabilidade Civil Frente Aos Aplicativos E-Commerce}

Preto, L.F. et al. (2014, p. 271) confirma que o direito francês exerceu grande influência sobre os demais códigos que foram surgindo, inclusive sobre o Código Civil Brasileiro de 1916.

Desta forma, a responsabilidade civil passou por várias etapas e contribuições, sempre buscando se adequar às novas realidades e necessidades sociais.

Em Portugal o Código Visigótico, devido a essas influências, tinha um sistema de caráter misto, fazendo parte dela a composição germânica e o critério penal dos romanos. O código nunca conseguiu estabelecer diferença entre responsabilidade civil e penal. "... embora considerasse o homicídio involuntário não sujeito a pena alguma, como gerador de reparação civil, em favor dos parentes da vítima, porque a composição era considerada pena" (PAULO apud DIAS, 1997, s/d)

\subsection{CONTORNOS INICIAIS SOBRE A RESPONSABILIDADE CIVIL.}

Oliveira (2012) ressalta que a teoria da responsabilidade civil se solidifica no princípio fundamental do neminemlaedere (dever de não lesar; a ninguém ofender), sendo justificado diante da liberdade e da racionalidade humanas. Logo, é possível compreender que a atitude de um agente que vem a causar dano, injustamente, a outrem faz com que exista o sofrimento do ônus relativo a fim de que se possa recompor a posição do lesado ou mitigar-lhe os efeitos do dano, ao mesmo tempo em que se faça sentir ao lesante o peso da resposta compatível prevista na ordem jurídica.

O vocábulo responsabilidade verifica-se que sua origem provém do verbo latino respondere, significando a obrigação que alguém tem de assumir com os efeitos jurídicos de sua conduta, contendo ainda, a raiz latina de spondeo, fórmula através da qual se vinculava no

Direito Romano o devedor nos contratos verbais. (DIAS, 2002, p. 02) Rui Stoco (apud Oliveira, 2012), em seu tratado de responsabilidade civil, ressalta que o nascimento da obrigação de indenizar foi firmado pelo art. 927 do Código Civil, que preceitua que aquele que por ato ilícito causar dano a outrem fica obrigado a repará-lo. Afirma também que tal obrigação deve ter como antecedentes os pressupostos fundamentais da responsabilidade civil, sendo eles os elementos formadores daquela obrigação. Ou seja, deve haver um comportamento que indique ação ou omissão do agente, deve haver dolo ou culpa o nexo causal entre a conduta e o resultado e a ocorrência real de um dano, excluindo-se o elemento subjetivo apenas nas hipóteses de responsabilidade objetiva

Em resumo, para Alcântara, seu fundamento reside na: 


\section{A Responsabilidade Civil Frente Aos Aplicativos E-Commerce}

Alteração do equilíbrio social, produzida por um prejuízo causado a um dos seus membros. O dano sofrido por um indivíduo preocupa todo o grupo porque, egoisticamente, todos se sentem ameaçados pela possibilidade de, mais cedo ou mais tarde, sofrerem os mesmos danos, menores, iguais e até maiores. (ALCÂNTARA, 1971, p. 81)

A responsabilidade civil estabeleceu ao longo dos anos grandes mudanças, sendo transformadas a fim de atender as necessidades que surgem da sociedade. Busca em seu sentido estrito não deixar que nenhuma vítima de dano fique sem reparação, proporcionando uma grande extensão dos danos que são passíveis de indenizações. A ideia sobre a responsabilidade civil se define como aplicações de meios alternativos que obriguem alguém a reparar o dano causado a outrem em face de uma ação ou omissão.

Nessa perspectiva, Stoco (2007, p. 114) agrega que:

A noção da responsabilidade pode ser haurida da própria origem da palavra, que vem do latim respondere, responder a alguma coisa, ou seja, a necessidade que existe de responsabilizar alguém pelos seus atos danosos. Essa imposição estabelecida pelo meio social regrado, através dos integrantes da sociedade humana, de impor a todos o dever de responder por seus atos, traduz a própria noção de justiça existente no grupo social estratificado. Revela-se, pois, como algo inarredável da natureza humana.

Entende-se a responsabilidade civil como a obrigação imposta por normas, levando as pessoas responderem pelas suas ações e omissões prejudiciais a alguém, e outros a conceituam sob o aspecto mais amplo, comportando duas modalidades de responsabilidade: a objetiva e subjetiva.

Silvio de Salvo Venosa (2012) expõe que o termo responsabilidade é utilizado em qualquer situação na qual alguma pessoa, natural ou jurídica, deva arcar com as consequências de um ato, fato, ou negócio danoso. Sob essa noção, toda atividade humana, portanto, pode acarretar o dever de indenizar. Desse modo, o estudo da responsabilidade civil abrange todo o conjunto de princípios e normas que regem a obrigação de indenizar.

De acordo com Diniz (2007, p.34):

Poder-se-á definir a responsabilidade civil como a aplicação de medidas que obriguem alguém a reparar o dano moral ou patrimonial causado a terceiros em razão de ato próprio imputado, de pessoa por quem ele responde, ou de fato de coisa ou animal sob sua guarda ou, ainda, de simples imposição legal. Definição esta que guarda, em sua estrutura, a ideia de culpa quando se cogita da existência de ilícito (responsabilidade subjetiva), e a do risco, ou seja, da responsabilidade sem culpa (responsabilidade objetiva). 


\section{A Responsabilidade Civil Frente Aos Aplicativos E-Commerce}

Pressupõe-se que a responsabilidade civil pode ser avaliada como uma obrigação que alguém se incumbe ao reparar um prejuízo causado por ela mesma, ou outra pessoa a que elas dependam (RODRIGUES, 2003, p. 6).

Define-se a responsabilidade civil nos seguintes moldes:

Em apertada síntese, responsabilidade civil é um dever jurídico sucessivo que surge para recompor o dano decorrente da violação de um dever jurídico originário. Só se cogita, destarte, de responsabilidade civil onde houver violação de um dever jurídico e dano. Em outras palavras, responsável é a pessoa que deve ressarcir o prejuízo decorrente da violação de um precedente dever jurídico.(CAVALIERI FILHO, 2007, p. 2 apud NUNES; LIGERO, 2009, p. 3),

Isto posto, constata-se que responsabilidade civil concerne à consequência jurídica advinda de todo e qualquer tipo de dano causado a terceiro. Ou seja, vale salientar que sempre que há uma conduta causadora de dano, o indivíduo poderá responder judicialmente por este ato. (NUNES E LIGERO, 2009)

Carlos Roberto Gonçalves (2011), em sua obra, depreende que "A responsabilidade civil tem, pois, como um de seus pressupostos, a violação do dever jurídico e o dano. Há um dever jurídico originário, cuja violação gera um dever jurídico sucessivo ou secundário, que é o de indenizar o prejuízo"(apud, Soares Neto, 2018)

Ao atermar o termo "responsabilidade civil", Pereira (1992, p.11) leciona que:

Consiste na efetivação da reparabilidade abstrata em relação a um sujeito passivo da relação jurídica que se forma. Reparação e sujeito passivo compõem o binômio da responsabilidade civil, que então se enuncia como o princípio que subordina a reparação à sua incidência na pessoa do causador do dano.

Nesse contexto, observa-se que a finalidade do instituto da responsabilidade civil é restabelecer o equilíbrio perdido pela vítima, em virtude do dano que Ihe foi acometido. Jhering (1990, p. 38 apud Moraes, 2006), julga que o surgimento da responsabilidade exigia que a vítima conseguisse provar a quebra de um dever de cautela, de um padrão de conduta exigível por parte do agente que causou o dano. Esta exigência de uma avaliação éticojurídica do comportamento do causador do dano para imputar-lhe o dever de repará-lo era tida como princípio axiomático, correspondente à ideia de punição pelo ilícito cometido.

Seifert (2002) classifica a responsabilidade em civil e penal. A partir de um único fato, é possível que ocorram danos em duas esferas, merecendo tratamento e soluções distintas, porém paralelas. De um fato pode ocorrer 1) um mal causado ao corpo social, sendo causa de pena, e, ao mesmo tempo, um 2) mal causado especificamente à vítima, sendo causa de indenização. O que diferencia uma da outra 


\section{A Responsabilidade Civil Frente Aos Aplicativos E-Commerce}

é o valor protegido. Enquanto na responsabilidade civil mais se protege um interesse privado de ressarcimento, na responsabilidade penal, o interesse geral de reprovação prepondera.

\subsubsection{RESPONSABILIDADE OBJETIVA}

Enquanto a responsabilidade civil subjetiva se baseia na culpa, a responsabilidade civil objetiva se fundamenta na teoria do risco porque, em meio à nova realidade do mundo moderno, em que os bens necessários à sobrevivência do corpo social são produzidos em escala industrial e existe a crescente utilização de máquinas sofisticadas em substituição ao trabalho humano, não é permitido, na maioria dos casos, que se impute o ato lesivo ao comportamento do homem. (BRASIL, 2012)

Por sua vez, a responsabilidade objetiva, é "baseada na justiça do "olho por olho" e do "dente por dente" do Talião, preocupada com o aspecto patrimonial em prejuízo das pessoas. Longe de significar a volta do primitivismo, reflete a sensibilidade do doutrinador ante os fenômenos sociais, consequentes e inevitáveis nos tempos de hoje" (FRANÇA, 2017, p. 144).

O parágrafo único do art. 927, que assim dispõe: “Haverá obrigação de reparar o dano, independentemente de culpa, nos casos especificados em lei, ou quando a atividade normalmente desenvolvida pelo autor do dano implicar, por sua natureza, risco para os direitos de outrem".

Para Ronaldo Gerad Seifert (2002), a teoria da responsabilidade objetiva se desenvolveu justamente quando os valores individuais perdiam força frente aos interesses coletivos. Nasce quando o indivíduo começa a perder sua extrema liberdade em favor do interesse do todo, quando começa a noção de que as relações privadas devem estar adequadas à sua função social.

Stoco (2004) menciona que a doutrina objetiva, ao invés de exigir que a responsabilidade civil seja a resultante dos elementos tradicionais (culpa, dano, vínculo de causalidade entre uma e outro) assentase na equação binária cujos polos são o dano e a autoria do evento danoso. Sem cogitar da imputabilidade ou investigar a antijuridicidade do fato danoso, o que importa para assegurar o ressarcimento é a verificação se ocorreu o evento e se dele emanou o prejuízo. (STOCO, 2004)

Na responsabilidade objetiva, subtrai-se a culpa, ou seja, o causador da ação responde sem culpa, pois a norma se baseia na teoria do risco, a qual menciona que o prejuízo deve ser atribuído ao seu autor e reparado por quem o causou, independentemente de ter, ou não, agido com intenção. Responsável é aquele que causou o dano, não importando o que ele tenha a dizer. (CORDEIRO, MENDONÇA, OLIVEIRA, NOGUEIRA, 2011). 
Esta forma de responsabilidade é, por vezes, defendida na base de que é no interesse da 'sociedade' que aqueles que sofram acidentalmente danos devem ser indenizado, e argumenta-se que a via mais fácil para fazê-lo é impor o encargo àqueles de cujas atividades, por mais cuidadosamente fiscalizadas que sejam, resultam tais acidentes.

Essas pessoas têm geralmente largos recursos e oportunidades para se segurarem contra tais riscos. Quando este argumento é avançado, há nele um apelo implícito ao bem-estar geral da sociedade que difere, embora possa ser moralmente aceitável e algumas vezes chamado mesmo de 'justiça social', das formas primárias equilíbrio, ou ordem de igualdade, estabelecido pela moral; a justiça exige então que este status quo moral seja reposto na medida do possível pelo autor do ilícito. (HART, apud. MENEGATT).

Fernando Noronha (2003 apud Carrá s/d) defende que a doutrina da responsabilidade objetiva atinge o formato da responsabilidade agravada, onde o risco (perigo) resultante das atividades desenvolvidas é de tal forma sensível aos interesses sociais que ainda subsistiria o dever de indenizar diante de certos eventos aptos a romper ou interromper o nexo causal.

“Aqueles casos fortuitos e de força maior que puderem ser considerados riscos típicos da atividade não excluirão a obrigação de indenizar".

A responsabilidade objetiva surge como uma opção aos casos em que a doutrina subjetivista não conseguirá solucionar. Consagrada no §6으 do artigo 37 da Carta Magna, a Teoria da Culpa Objetiva, refere-se ao dever de indenizar o dano causado, independente da culpa do agente causador. (PINHO, 2008).

Isto posto, importante destacar que a Responsabilidade Objetiva não exclui a

Responsabilidade Subjetiva, mas sim, a complementou, visto que, ambas subsistem, no intuito de atender aos anseios dos mais diversos casos concretos, de maneira a promover justiça e proteger a vítima.

\subsubsection{RESPONSABILIDADE SUBJETIVA}

A responsabilidade civil subjetiva pode ser definida como aquela que se impõe a uma conduta humana (ação ou omissão) que viole o direito de uma segunda pessoa. Diz-se subjetiva a responsabilidade quando se baseia na culpa do agente, que deve ser comprovada para gerar a obrigação indenizatória (MATIELO F. Z., 2014, p. 70).

A cláusula geral relativa ao tema, que no Código Civil de 1916 estava consubstanciada no art. 159, agora resulta da fusão de dois dispositivos legais - os arts. 186 e 927, caput. 


\section{A Responsabilidade Civil Frente Aos Aplicativos E-Commerce}

Efetivamente o art. 186 estabelecia um preceito segundo o qual "aquele que, por ação ou omissão voluntária, negligência ou imprudência, violar direito e causar dano a outrem, ainda que exclusivamente moral, comete ato ilícito", ao passo que o caput do art. 927 prevê as consequências jurídicas de tal fattispecie: "aquele que, por ato ilícito (arts. 186 e 187), causar dano a outrem, fica obrigado a repará-lo".

Caio Mário da Silva Pereira (2002), ensina que na teoria da responsabilidade subjetiva, o que sobressai no foco das considerações e dos conceitos é a figura do ato ilícito, como ente dotado de características próprias, e identificado na sua estrutura, nos seus requisitos, nos seus efeitos e nos seus elementos.

A teoria da culpa subjetiva foi consagrada pelo Direito Brasileiro, a partir do Código Civil de 1916 (artigo 159) e no atual Código Civil está no art. 186 e no Código de Defesa do Consumidor em seu artigo 14, §4․ Resulta daí que a comprovação da culpa, em face dos atos praticados pelo agente, é determinante em nosso ordenamento jurídico, principalmente para a averiguação do quantum indenizatório. Nesse sentido, a ordem jurídica leva em consideração o fato humano voluntário, sobre o qual repousa toda a construção dos efeitos jurídicos. (PINHO, 2008).

A responsabilidade civil subjetiva pode ser definida como a obrigação de reparar o dano imposta a todo aquele que, por ação ou omissão voluntária, negligência ou imprudência, violar direito ou causar prejuízo a outrem. Neste contexto, torna-se necessário comprovar a conduta, o dano, o nexo causal e culpa do agente, onde o causador do dano só deverá indenizar a vítima se ficar caracterizada a culpa.

Kfouri Neto (2002) define a subjeção da responsabilidade como a necessidade de um ato ou omissão que viole o direito de uma segunda pessoa, o dano produzido por este ato ou omissão, a responsabilidade de causalidade entre o ato ou omissão e o dano e, finalmente, a culpa.

A responsabilidade civil subjetiva está vinculada à ocorrência de um ato ilícito. Ato ilícito é todo ato contrário ao Direito ou à moral. No início, os atos ilícitos eram subdivididos em delitual e quase-delito. Em uma das concepções dessa subdivisão, delitual seria o ato que desrespeitasse uma proibição legal ou que tivesse uma pena expressa. Quase-delitos eram os atos que causassem um mal equiparável mas sem previsão casuística, sem previsão legal específica para o fato. Em qualquer dos casos, carregam o valor de reprovação. Por não haver distinção relevante para o direito civil, não se cogita mais essa subdivisão. Basta que seja contrário ao Direito ou à moral. (SEIFERT, 2002).

Fala-se em responsabilidade subjetiva, quando o agente age com culpa. Provar a culpa passa a ser pressuposto essencial para o nascimento do dever de reparar, de tal sorte que apenas haverá responsabilização do agente causador do dano se este agir com dolo ou culpa. (GONÇALVES, 2010) 


\section{A Responsabilidade Civil Frente Aos Aplicativos E-Commerce}

\subsubsection{RESPONSABILIDADE CIVIL CONTRATUAL}

A responsabilidade civil contratual liga-se à ideia da reparação dos danos causados em virtude do descumprimento de uma obrigação contratual preexistente. Desta forma, o descumprimento de uma norma jurídica contratual, previamente fixada pelas partes em um contrato, pode redundar em responsabilização civil contratual por eventuais danos ocorridos, ocasião em que a parte que descumpriu a obrigação contratual poderá ver-se compelida a reparar os danos causados a outra ou as outras partes que compõem a relação contratual.

A tal respeito, Pablo Stolze Gagliano e Rodolfo Pamplona Filho afirmam que "[...] se, entre as partes envolvidas, já existia norma jurídica contratual que as vinculava, e o dano decorre justamente do descumprimento de obrigação fixada neste contrato, estar-se-á diante de uma situação de responsabilidade contratual" (GAGLIANO; PAMPLONA FILHO, 2012,

p.62).

Na responsabilidade civil contratual exige-se um vínculo anterior entre o autor e a vítima e o descumprimento de uma obrigação de norma jurídica preexistente, e que para reparação do dano basta ser provado seu descumprimento, diferentemente da responsabilidade civil extracontratual. (DIAS, MESSIAS, 2019).

O artigo 389 do NCC3 trata dos efeitos resultantes da responsabilidade civil oriunda dos contratos. Dispõe o Artigo 389: “ Art. 389. Não cumprida a obrigação, responde o devedor por perdas e danos, mais juros e atualização monetária segundo índices oficiais regularmente estabelecidos, e honorários de advogado." Ou seja, o dever de indenizar nasce do descumprimento de uma obrigação contratual prevista.

Assim, diante da existência de uma convenção contratual prévia e da falta de seu adimplemento, surge à obrigação de reparar os danos eventualmente causados. Para que haja a responsabilização civil daquela parte que deixou de cumprir a norma contratual e causou danos às outras partes contratantes, basta a comprovação de que a obrigação não foi comprida, pois, neste caso, a culpa é presumida, sendo incumbida ao devedor a prova de eventual cumprimento da obrigação ou a ocorrência de uma das excludentes legais de responsabilização previstas no

Art. 393, do Código Civil brasileiro "[...] culpa exclusiva da vítima, caso fortuito ou força maior. Incumbe-Ihe, pois, onus probandi" (GONÇALVES, 2012, p.44).

Segundo o Novo Código Civil (NCC) brasileiro, no ato em que o profissional aceita alguém como paciente estabelece-se entre as partes um contrato de trabalho (Gomes, Candelária e Silva, 1997 apud 


\section{A Responsabilidade Civil Frente Aos Aplicativos E-Commerce}

Kfouri Neto, 2003), mesmo se este for de natureza verbal (contrato de locação de serviço). Entretanto, excepcionalmente, tal responsabilidade pode ser de natureza extracontratual, e isso ocorre no caso de o profissional participar de um atendimento de emergência, conforme aspectos mencionados no próximo tópico.

\subsubsection{RESPONSABILIDADE CIVIL EXTRACONTRATUAL}

A responsabilidade civil extra-contratual, por sua vez, teria por fundamento a imputação de um dever de indenizar independente da existência de um prévio vínculo entre o agressor e o lesado, justificandose, exclusivamente, pela ocorrência de um dano imputável ao agressor.

Maria Helena Diniz afirma que:

A responsabilidade extracontratual, delitual ou aquiliana decorre de violação legal,ou seja, de lesão a um direito subjetivo ou da prática de um ato ilícito, sem que haja nenhum vínculo contratual entre lesado e lesante. Resulta, portanto, da inobservância da norma jurídica ou de infração ao dever jurídico geral de abstenção atinente aos direitos reais ou personalidade, ou melhor, de violação à obrigação negativa de não prejudicar ninguém (DINIZ, 2014, p.577).

A responsabilidade extracontratual tem sua fonte na lei, estabelecida basicamente no Artigo 186 do NCC3: “Aquele que, por ação ou omissãso voluntária, negligência ou por imprudência violar direito e causar dano a outrem, ainda que exclusivamente moral, comete ato ilícito". É prevista também nos artigos 187 e 188, bem como nos artigos 927 a 954, todos do Novo Código Civil.

Ao contrário da responsabilidade civil contratual, a responsabilidade civil extracontratual não advém de uma relação jurídica preexistente, ela decorre de um ato ilícito, de um descumprimento de um dever legal ou violação direta de uma norma legal sem que exista uma relação anterior entre a vítima e o ofensor.

A diferença básica entre a responsabilidade contratual e a extracontratual, segundo o jurista Rodrigues (1993), é que "na hipótese de responsabilidade contratual, antes de a obrigação de indenizar emergir, existe, entre o inadimplente e seu co-contratante, um vínculo jurídico derivado da convenção; na hipótese da responsabilidade extracontratual, nenhum liame jurídico existe entre o agente causador do dano e a vítima até que o ato daquele ponha em ação os princípios geradores de sua obrigação de indenizar".

No que tange à responsabilidade civil extracontratual a regra do atual Código Civil brasileiro é a responsabilidade subjetiva. Isto significa dizer que, em regra, a prova da culpa incumbe à vítima, cabendo, assim, a ela provar que o ofensor agiu com negligencia, imprudência ou imperícia. 


\section{A Responsabilidade Civil Frente Aos Aplicativos E-Commerce}

Essa dualidade seria um reflexo de um dos pilares do Estado Liberal, segundo o qual a liberdade dos indivíduos - bem como a estipulação de restrições e sanções ao exercício dessa liberdade -, somente poderia ter por fonte, ou um ato de autonomia privada ou uma regra legal, geral e abstrata (Couto e Silva, 1997, p. 199)

É nesse sentido que Geniviève Viney - partindo do tradicional pensamento de Charles Sainctelette -, explica que o binômio entre a responsabilidade civil contratual e extracontratual seria proveniente de uma oposição radical entre a Lei e o contrato.

\subsection{RESPONSABILIDADE CIVIL NAS RELAÇÕES DE CONSUMO}

O CDC criou um microssistema próprio, por se colocar, no ordenamento jurídico, como uma lei principiológica, pelo que a ela devem se subordinar todas as leis específicas quando tratarem de questões que atinem a relações de consumo. Compondo um sistema autônomo dentro do quadro constitucional. É um subsistema próprio, inserido no sistema constitucional brasileiro.

Uma relação de consumo, de forma imperiosa, possui dois elementos que nunca deverão mudar: fornecedor e consumidor. Sem estas duas figuras basilares não há que se falar em relação de consumo. Há ainda que se dar atenção aos demais elementos, tais como motivação, oferta, vontade das partes e o próprio contrato em si.

Destaca-se o entendimento dado por Bonatto (2004):

São elementos da relação de consumo, segundo o Estatuto Protetivo: a) como sujeitos: o consumidor e o fornecedor; b) como objeto: produto ou serviço; c) como finalidade, caracterizando-se como elemento teleológico das relações de consumo: a aquisição ou a utilização do produto ou serviço, por parte do consumidor, como destinatário final.

Os princípios informadores da relação de consumo, ou seja, as raízes orientadoras do sistema jurídico são: a vulnerabilidade do consumidor; a boa-fé objetiva; transparência; educação e informação; proibição das cláusulas abusivas e responsabilidade civil objetiva do fornecedor.

Cavalieri Filho (2008) sustenta a aplicação do Código de Defesa do Consumidor a todas as relações de consumo, independentemente da área do direito em que ocorrerem, e assim as define:

Relação de consumo é a relação jurídica, contratual ou extracontratual, que tem numa ponta o fornecedor de produtos e serviços e na outra o consumidor; é aquela realizada entre o fornecedor e o consumidor tendo objeto a circulação de produtos e serviços.

Havendo circulação de produtos e serviços entre o consumidor e o fornecedor, teremos relação de consumo regulada pelo Código de Defesa do Consumidor 


\section{A Responsabilidade Civil Frente Aos Aplicativos E-Commerce}

(CAVALIERI FILHO, 2008, p. 469).

Para a aplicação do Código de Defesa do Consumidor é necessário que haja uma Relação Jurídica de Consumo, que entendemos como uma relação que pressupõe dois sujeitos: de um lado o consumidor e do outro o fornecedor, tendo por objeto a aquisição de um produto ou a utilização de um serviço.

A regra geral adotada pelo Código de Defesa do Consumidor, relativamente à responsabilidade civil dos prestadores de serviços, está estampada no caput do artigo 14 da Lei no 8.078/90, in verbis:

Art. 14. O fornecedor de serviços responde, independentemente da existência de culpa, pela reparação dos danos causados aos consumidores por defeitos relativos à prestação dos serviços, bem como por informações insuficientes e inadequadas sobre sua fruição e riscos (BRASIL, 2013a).

O Código de Defesa do Consumidor como regra geral, a teoria da responsabilidade objetiva do fornecedor de serviços, isto é, institui a responsabilidade sem culpa. Trata-se, como se vê, de uma garantia de que o serviço será fornecido ao consumidor sem defeito, de sorte que, ocorrido o acidente de consumo, não se discute culpa; o fornecedor responde por ele simplesmente, porque lançou no mercado um serviço com defeito. E mais, será absolutamente irrelevante saber se o fornecedor tinha ou não conhecimento do defeito, bem como se esse defeito era previsível ou evitável. Em face do fato do serviço, o defeito é presumido, porque o Código diz - art. 14, § 3ำ I - que o fornecedor só excluirá a sua responsabilidade se provar - ônus seu - que o defeito inexiste, vale dizer, que o acidente não teve por causa um defeito do serviço (CAVALIERI FILHO, 2008, p. 383).

De acordo com a sistemática adotada pelo Código Civil, no que não difere do anterior, a regra é a adoção da teoria subjetiva, baseada na culpa do agente, para sua responsabilização.

Há casos, porém, em que não só o Código, como também a legislação esparsa, contempla a teoria objetiva. (CASTRO FILHO, 2005).

O que basicamente diferencia ambas as teorias é a necessidade ou não da presença do elemento culpa, só imprescindível na subjetiva. Entretanto, as teorias subjetiva e objetiva em nada se diferenciam no que tange aos outros dois pressupostos da responsabilidade: existência de dano e nexo de causalidade entre a ação do agente (ou fato gerador) e o resultado danoso. (CASTRO FILHO, 2005)

Define-se culpa como: "Inexecução de um dever que o agente podia conhecer e observar. Se efetivamente o conhecia e deliberadamente o violou, ocorre o delito civil, ou em matéria de contrato, o dolo contratual".(SAVATIER, 1951, p. 92 apud ANDRADE, 2003) 


\section{A Responsabilidade Civil Frente Aos Aplicativos E-Commerce}

O grau de culpa restará disposto nos artigos 944 e 945 do Código Civil, momento pelo qual o dano se apresenta consumado. A verificação do grau de culpa tem como intuito a avaliação para a respectiva indenização dada a responsabilidade civil do autor.

Já o dano se caracteriza como uma lesão a um bem protegido juridicamente, de modo a gerar prejuízos tanto na ordem patrimonial, quanto na extrapatrimonial. Isto é, o dano é elemento substancial na configuração do instituto da responsabilidade civil.

Sobre o dano, conceitua o doutrinador Cavalieri Filho como (2005, p. 95):

[...] sendo a subtração ou diminuição de um bem jurídico, qualquer que seja a sua natureza, quer se trate de um bem patrimonial, quer se trate de um bem integrante da própria personalidade da vítima, como a sua honra, a imagem, a liberdade etc. Em suma, dano é lesão de um bem jurídico, tanto patrimonial como moral, vindo daí A conhecida divisão do dano em patrimonial e moral.

Não há responsabilidade sem dano, pois, o dano é o fato gerador da responsabilidade de pagamento de indenização ou de reparação. Pode haver responsabilidade sem culpa, mas não responsabilidade sem dano. Pode o agente praticar conduta culposa ou dolosa que abuse de direito, mas que, se não causar dano, não haverá que se cogitar em responsabilidade de indenização. (CASSAR, 2010, apud Oliveira 2012).

Cairo Júnior (2002), enseja que entre o dano efetivo e a ação ou omissão, deve haver, sob pena de exclusão da responsabilidade do agente, um elo que é denominado de nexo causal.

Se o ato ou fato não foi condição necessária ou contribuiu de qualquer forma para o evento danoso (concausalidade), não há falar-se em responsabilidade civil. A culpa exclusiva da vítima, o caso fortuito e a força maior, ensejam a exclusão da responsabilidade civil.

A relação de causalidade é um dos elementos essenciais para a responsabilidade civil, haja vista que atua como elo entre a conduta do agente e o dano. (VENOSA, 2006)

Ou seja, o nexo causal é o elemento necessário para que se possa determinar a quem deve atribuir-se o resultado danoso, bem como a extensão do dano causado e o quantum indenizatório. Logo, o nexo causal diz respeito ao vínculo existente entre a conduta e o resultado. (CAVALIERI, 2002)

Vilson Rodrigues Alves destaca que:

Na responsabilidade objetiva abstrai-se a culpa. Há mero nexo de causalidade exterior: a obrigação de indenizar decorre da simples relação de causa e efeito entre o fatocausa e o fato-consequência. Diversamente das hipóteses em que a responsabilidade civil é aferida no campo da responsabilidade subjetiva, na qual a regra é a irresponsabilidade civil, salvo a demonstração do nexo de 


\section{A Responsabilidade Civil Frente Aos Aplicativos E-Commerce}

causalidade entre a conduta do agente e o dano, na responsabilidade civil objetiva a não irresponsabilidade civil é a regra: dados o dano e a autoria do dano, a responsabilidade civil pela indenização desse dano é, em princípio, inafastável, sem mais (ALVES apud NETO, 2010, p. 91).

Não obstante a regra seja a responsabilização sempre que se verifique essa relação de causa e efeito, há excludentes previstas na própria lei, tais são o estado de necessidade, a legítima defesa, o exercício regular de direito ou cumprimento de dever legal, além do caso fortuito ou força maior. O estado de necessidade, todavia, não chega a ser uma excludente perfeita, uma vez que doutrina e jurisprudência têm entendido que, em tais situações, o prejuízo deve ser reparado. Outra excludente que se tem reconhecido é o fato de terceiro, tendo em vista a ausência do elemento causalidade entre a ação e o efeito, o que muito o assemelha ao caso fortuito. (CASTRO FILHO, 2005).

Todavia empresas, ao praticarem alguma atividade no mercado, devem fazê-la no sentido de não provocar riscos à vida, à saúde, à segurança dos consumidores, devem também colocar produtos e serviços de qualidade. Da prática disforme dessas atividades é que será imputada a responsabilidade de reparar os vícios e os defeitos ocasionados.

Os principais eixos de proteção do consumidor estendem-se desde a fase pré-contratual, até a póscontratual, passando pela fase contratual propriamente dita e visam em linha gerais à proteção contra práticas comerciais desleais e abusivas, informação, educação do consumidor e a proteção contra produtos ou serviços defeituosos ou com vícios. A responsabilidade civil do fornecedor está inserida neste último eixo, representando um dos mais significativos aspectos da proteção do consumidor, porque objetiva reparar o consumidor dos prejuízos causados pela introdução de produtos ou serviços defeituosos ou com vícios, no mercado de consumo científica.

\section{DA RESPONSABILIDADE CIVIL DAS EMPRESAS E-COMMERCE}

\subsection{RELAÇÕES DE CONSUMO POR E-COMMERCE}

O caráter global da internet e a ausência de um domínio único sobre suas dimensões impõem a reflexão acerca dos efeitos do mundo virtual na vida real de seus usuários. Nesse sentido, ressalta-se o equívoco da afirmação de que a internet seria o meio da livre e irrestrita circulação de informações, onde qualquer espécie de restrição ou censura seria vedada (GREENBERG, 2016).

Com a evolução da tecnologia, houve drásticas mudanças nos modos de consumo, e com isso, responsabilidade civil foi uma das aéreas do direito que mais sofreu alterações. Como se sabe nos 


\section{A Responsabilidade Civil Frente Aos Aplicativos E-Commerce}

últimos anos, surgiram os aplicativos para smartphone, criando novas formas de se contratar um serviço delivery de alimentos, bebidas e outros bens de consumo.

Esse novo tipo de relação cria situações a serem enfrentadas à luz do regime de responsabilidade civil estabelecido no Código Civil, bem como, pelo Código de Defesa do Consumidor. Seriam as regras existentes suficientes para tutelar o novo modelo de consumo, em que existe um aplicativo intermediador, um estabelecimento comercial e um entregador, todos envolvidos na prestação do serviço? Neste sentido, "a discussão sobre os limites de aplicação das normas jurídicas às relações estabelecidas por meio da internet diz respeito, em verdade, à eficácia e efetividade da norma na regulação de um determinado suporte fático sobre o qual deve incidir“ (MIRAGEM, 2016).

Para que ocorra a aplicação do Código de Defesa do Consumidor é preciso que seja caracterizada a relação de consumo entre o fornecedor e o destinatário final, sendo que dentro do próprio ordenamento há a definição dos conceitos de consumidor e fornecedor, assim como do que é caracterizado como um produto ou serviço.

Os requisitos para ser caracterizada uma relação de consumo estão presentes nos negócios de ecommerce, sendo que mesmo que o sitio eletrônico se apresente como um serviço gratuito, o mesmo está presente na cadeia de remuneração. Isto posto, como bem explica a doutrinadora Cláudia Lima Marques, que ao analisar a atividade dos fornecedores e sites eletrônicos afirma que "estas atividades dos fornecedores visam lucro, são parte de seu marketing e de seu preço total, pois são remunerados na manutenção do negócio principal" O comércio eletrônico, e-commerce, ou comércio e pode ser conceituado como o conjunto de relações travadas entre fornecedor e consumidor, realizada em um estabelecimento empresarial virtual, através, ou não, da internet.

Nesse sentido, importante verificar o seguinte comentário feito por José Wilson Boiago Junior sobre o assunto:

\footnotetext{
Diante destes fatores é que o direito deve regular as relações contratuais eletrônicas, pois o mercado digital exige regras, tendo em vista as questões de proteções ao consumidor, privacidade de dados, assinatura digital, correio eletrônico, bem como outros aspectos de grande relevância no ciberespaço. (BOIAGO JÚNIOR, 2011, p.43).
}

Há diferentes espécies de contratos previstos no ordenamento jurídico, cabe frisar o contrato de adesão. O contrato de adesão é oferecido ao público em um modelo uniforme, geralmente impresso, faltando apenas preencher os dados referentes à identificação do consumidor-contratante, do objeto e do preço. (MARQUES, 2005. p. 71). Esta modalidade de contrato se assemelha aos Termos de Uso 


\section{A Responsabilidade Civil Frente Aos Aplicativos E-Commerce}

que estão presentes nos sites de vendas na internet, possibilitando o fácil acesso dos consumidores às condições contratuais. Trata-se de contratos onde estão previstas cláusulas no que tange ao funcionamento do site, cadastro de usuários, vendas, entregas, fretes, responsabilidades do fornecedor e das empresas intermediadoras, bem como, acerca dos meios de pagamento efetuados pelo site.

Segundo Finkelstein (2011), aos contratos eletrônicos se aplicam as mesmas regras aplicadas aos contratos celebrados fisicamente "quanto à capacidade, objeto, causa e efeitos".

Demais implicações emanam de codificações e leis esparsas ou então da aplicação subsidiária da legislação existente como forma de tentar suprir a lacuna legal deixada quanto à matéria.

Maciel e Porto explicam que por analogia, que aqueles presentes -Termos de Uso disponibilizados pelos sites na internet, os quais serão analisados no decorrer do presente estudo, seja uma espécie de contrato entre as partes, uma vez que há um vínculo entre o consumidor e o vendedor do produto ou serviço, no espaço eletrônico.

O que se observa ao analisar estes termos é que os mesmos se encaixam nitidamente como um contrato de adesão, ou seja, típico contrato que se apresenta com todas as cláusulas predispostas por uma das partes. A outra parte, o aderente, somente tem a alternativa de aceitar ou repelir o contrato. (VENOSA, 2017)

Conforme o exposto no artigo 434 do Código Civil, quando as partes estão ausentes no contrato, o mesmo se torna perfeito com a expedição da aceitação, tal situação é denominada teoria da expedição mitigada. Entretanto, diferentemente do que ocorre com os contratos, nos quais o envio da aceitação é realizado por um meio físico, como, por exemplo, uma correspondência pode perceber que no comércio eletrônico pode ocorrer da aceitação ser realizada apenas com um "clique" do usuário, não deixando vestígios da confirmação.

Gagliano e Filho (2017) norteiam que no que diz respeito à responsabilidade contratual é importante destacar que se refere a um -inadimplemento da obrigação prevista no contrato (violação de norma contratual anteriormente fixada pelas partes); Em contrapartida, na responsabilidade extracontratual, há uma - violação direta de uma norma legal. Ou seja, o dano decorreu da não observância de um preceito legal, ou melhor, de - um dever necessariamente negativo, ou seja, a obrigação de não causar dano a ninguém. Tal modalidade de responsabilidade encontra respaldo nos artigos 186 a 188 e 927 e seguintes do Código Civil de 2002. 


\section{A Responsabilidade Civil Frente Aos Aplicativos E-Commerce}

A responsabilidade civil encontra respaldo nos artigos 927 a 954 do Código Civil de 2002, que trata do tema no capítulo I do Título IX, disciplinando sobre a obrigação de indenizar e a indenização, que decorre de um ato ilícito (artigo 186, do CC). Sobre o conceito, cabe ressaltar:

Em princípio, toda atividade que acarreta prejuízo gera responsabilidade ou dever de indenizar. Haverá, por vezes, excludentes, que impedem a indenização, como veremos. $O$ termo responsabilidade é utilizado em qualquer situação na qual alguma pessoa, natural ou jurídica, deva arcar com as consequências de um ato, fato ou negócio danoso. Sob essa noção, toda atividade humana, portanto, pode acarretar o dever de indenizar. Desse modo, o estudo da responsabilidade civil abrange todo o conjunto de princípios e normas que regem a obrigação de indenizar. (VENOSA, 2017).

Ou seja, o objeto do contrato disponibilizado pelo site consiste em - ofertar e hospedar espaços nos sites para que usuários anunciem à venda seus próprios produtos e/ou serviços\|, e ainda tem como função - viabilizar o contato direto entre usuários vendedores e interessados em adquirir produtos e serviços anunciados [...].

Desse modo, no que diz respeito à responsabilidade civil, frisa-se que o Código de Defesa do Consumidor (Lei no 8.078/1990), a partir do art. 12, aborda a responsabilidade do fabricante, produtor, construtor e importador, assim como no art. 13 há a previsão de responsabilidade do fornecedor de forma objetiva, que estabelece:

O fornecedor de serviços responde independentemente da existência de culpa, pela reparação dos danos causados aos consumidores por defeitos relativos à prestação dos serviços, bem como por informações insuficientes ou inadequadas sobre sua fruição e riscos (BRASIL, 2021).

Os contratos interpessoais por sua vez ocorrem quando há a troca de mensagens e informações por meio eletrônico como, por exemplo, chats e emails, entre o vendedor e o consumidor, sendo que diferentemente dos contratos intersistêmicos, o modelo interpessoal necessita de ação direta da vontade humana. Por fim, existem também os contratos interativos, os quais são caracterizados pela compra do indivíduo de produtos em um website, por meio da escolha do produto e subsequente clique confirmatório da compra (BARROS, 2017).

Neste contexto, pode-se deduzir que os atos jurídicos praticados através de meio eletrônico, são equivalentes àqueles praticados tradicionalmente, ou seja, aqueles praticados por escrito - meio físico (LAWAND, 2003).

Santos (2019) evidencia que dessa forma, o Código de Defesa do Consumidor (CDC) de 1990 pode não ser suficiente para lidar com as atuais questões levantadas pelo comércio eletrônico, assim foi criado 


\section{A Responsabilidade Civil Frente Aos Aplicativos E-Commerce}

o Decreto 7962/2013 no dia 15 de março, responsável pela regulamentação do CDC, para tratar das relações de comércio eletrônico.

O dispositivo em questão busca equilibrar a vulnerabilidade do consumidor virtual frente às incertezas advindas das compras online, tendo se preocupado com a necessidade dos sites eletrônicos deixarem claras as informações para o consumidor. Tal preocupação pode ser vista desde seu artigo 1ํ, o qual afirmar que o decreto em estudo irá dispor sobre: 1) a obrigação de deixar claras as informações a respeito do produto, serviço e do fornecedor; 2) o atendimento facilitado ao consumidor e; 3) o respeito ao direito do arrependimento.

Em relação à prestação de informações, demonstrando o princípio da transparência, o qual se mostra com grande importância dentro do direito do consumidor, seus artigos $2 \circ$ e 30 apresentam obrigações dos sites e outros meios eletrônicos responsáveis pela disponibilização de ofertas e conclusão de contratos de compra e venda. (SANTOS, 2019)

Pinheiro (2016, p. 537), entende que o segundo diferencial dos contratos eletrônicos é:

[...] determinar objetivamente as responsabilidades das partes quanto à tecnologia, à segurança, ao conteúdo, ao produto, à entrega, ao banco de dados, às informações publicadas ou tornadas públicas, à atualização e ao upgrade. Devem existir cláusulas específicas, delimitando e definindo o grau de responsabilidade por todas essas questões e, principalmente, sobre a proteção da relação com o consumidor final, uma vez que o Código de Defesa do Consumidor é totalmente aplicável dentro do Direito Digital e das relações de consumo virtual.

Importante ressalvar que deve ser feita, porém, quanto ao fato de que a aplicabilidade do CDC ao comércio eletrônico se dá apenas quando os contratos virtuais firmados são nacionais. Não se engloba os contratos internacionais, pois com a descentralização do território, antes físico, em que se davam as contratações, e sem a definição do tempo e espaço anteriormente bem apresentados pela doutrina e jurisprudência, não há mais como se falar em limites de nacionalidade e territorialidade, já que agora o lugar da conclusão dos contratos e negócios firmados é determinado pelas partes que contratam. (SALGARELLI, 2010).

Então torna-se necessaria e urgente uma atualização no CDC com a finalidade de ampliar a proteção ao e-consumer e adaptar o CDC aos novos métodos aplicados ao comércio em âmbito eletrônico, seja na questão de direitos referentes ao consumidor final, seja quanto aos deveres dos fornecedores virtuais. Tendo isto em mente, vislumbra-se que se busca minimizar a vulnerabilidade do consumidor 


\section{A Responsabilidade Civil Frente Aos Aplicativos E-Commerce}

que, na internet, torna-se ainda mais hipossuficiente frente ao fornecedor, pois a compra em meio eletrônico ocorre na maioria das vezes "às cegas" por não conhecer quem está do outro lado da relação jurídica.

Entretanto, o consumidor deve sempre ter cautela em relação às informações obtidas na internet, tendo em vista que no meio virtual, existem mensagens com conteúdos falsos, podendo acarretar danos futuros àquele que tomar como verdadeira uma mensagem cujo conteúdo seja dissimulado.

Preceitua o professor Guilherme Magalhães Martins:

Tratando-se de relações de consumo cuja insegurança e risco avultam, num meio eletrônico reconhecidamente passível de violação, por meio de uma rede aberta, como a Internet, agrava o quadro da vulnerabilidade do consumidor, tido como a mais fraca das partes envolvidas. (MARTINS, 2008, p.45).

\subsection{ANÁLISE JURISPRUDENCIAL}

Dado essa grande evolução, se faz necessário o amparo de nosso Tribunais nessas relações, para que sejam criados precedentes e entendimentos uníssonos, afim de criar segurança jurídica e pacificar qualquer tipo de demanda.

Diante disso, vejamos o que vem entendendo nossos Tribunais Pátrios em casos entre aplicativos de serviços de deliverys e consumidores lesados.

SERVIÇOS DE ENTREGA POR APLICATIVO - Relação de consumo configurada

- "Golpe do delivery" - Cobrança de valor indevido feita pelo entregador, no ato da entrega - Responsabilidade objetiva da empresa intermediadora, não só por se tratar de relação de consumo, mas, também, pelo próprio risco da atividade exercida - Responsabilidade solidária de todos os atuantes da relação de consumo, independentemente de existência de vínculo de subordinação entre a empresa e o terceiro fraudador - Fato ínsito às atividades da empresa recorrente, que configura fortuito interno e não pode ser alegado para eximir sua responsabilidade - Tampouco restou configurada culpa exclusiva do consumidor - Falha na prestação do serviço - Dano material consistente na devolução do valor cobrado indevidamente de forma simples - Minoração do dano moral fixado - Sentença reformada - Recurso parcialmente provido.

(TJ-SP - RI: 10135926220208260562 SP 1013592-62.2020.8.26.0562, Relator: Renata Sanchez Guidugli Gusmão, Data de Julgamento: 30/11/2020, 3a Turma Cível - Santos, Data de Publicação: 11/12/2020).

No primeiro caso trazido neste tópico, notemos que o Tribunal de São Paulo qualifica a responsabilidade da empresa como objetiva ou seja aquela que indenpende de culpa ou dolo para a configuração do dano causado, haja vista que, o consumidor sempre será parte hipossuficiente nas relações de consumo. 
Tribunal de Justiça do Estado da Bahia PODER JUDICIÁRIO PRIMEIRA TURMA RECURSAL - PROJUDI PADRE CASIMIRO QUIROGA, LT. RIO DAS PEDRAS, QD 01, SALVADOR - BA ssa-turmasrecursais@tjba.jus.br - Tel.: 71 3372-7460 RECURSO INOMINADO № 0160707-26.2020.8.05.0001 RECORRENTE: ANDREZA CARLA NUNES PINTO SANTANA ADVOGADO: EDGAR PEREIRA DE SANTANA JUNIOR RECORRIDO: IFOOD AGENCIA DE SERVICOS E RESTAURANTES LTDA EPP ADVOGADO:

JUÍZO DE

ORIGEM: 12a VSJE DO CONSUMIDOR DE SALVADOR JUIZ RELATOR: ALBÊNIO LIMA DA SILVA HONORIO EMENTA RECURSO INOMINADO. CONSUMIDOR. IFOOD. DELIVERY. ALEGAÇÃO AUTORAL DE TER ADQUIRIDO 48 ESFIRRAS, ATRAVÉS DO APLICATIVO RÉU, NO ESTABELECIMENTO HABIBĊS, TENDO SOLICITADO QUE AS ESFIRRAS DE QUEIJO FOSSEM EMBALADAS SEPARADAS DAS ESFIRRAS DE CARNE E FRANGO, POIS POSSUI UM FILHO MENOR PORTADOR DE INTOLERÂNCIA À LACTOSE. REVELIA. SENTENÇA QUE JULGOU IMPROCEDENTES OS PEDIDOS. RECURSO DA AUTORA. BANALIZAÇÃO DOS DANOS MORAIS. IMPROCEDÊNCIA MANTIDA. RECURSO CONHECIDO E DESPROVIDO. RELATÓRIO Trata ( $\mathrm{m}$-) se de recurso (s) inominado (s) interposto (s) contra a sentença prolatada no processo em epígrafe nos seguintes termos: ¿Dispensado o relatório, na forma do artigo 38 da Lei no 9.099/95, passo a decidir. De início, cumpre registrar que embora citada, a parte ré não apresentou contestação, tampouco compareceu aos atos do processo, razão pela qual reconheço a revelia, nos termos do art. 20 da Lei no 9.099/95. Passo à análise do mérito. Imperioso registrar que no presente caso há a configuração de relação de consumo entre as partes, razão pela qual a demanda deve ser analisada à luz do Código de Defesa do Consumidor.

De pronto o Tribunal entendeu que houve relação de consumo, e por isso a demanda será analisada a luz do CDC, bem como, a ré foi considerada revel, haja vista que, foi devidamente citada, porém, se manteve inerte na lide.

Com efeito, com relação à repartição do ônus da prova, a inversão do ônus da prova autorizada pelo art. 6으, inciso VIII, do CDC não incide de maneira automática. Tratase, na verdade, de regra de instrução processual que não foi anunciada no curso do processo. Nessa linha, depreende-se dos elementos constantes nos autos que a autora solicitou uma entrega do restaurante Habibis através do aplicativo da ré Ifood, fazendo uma observação de que as esfirras que continham queijo deveriam vir separadas das esfirras de carne e frango. Informa ainda que tem um filho intolerante à lactose e a conduta da ré teria prejudicado seu lanche em família. Alega que o restaurante não atendeu a sua solicitação, e pleiteia danos morais, além da devolução em dobro do valor pago. Nessa linha, examinando a questão posta em juízo, depreende-se dos elementos presentes no processo que a pretensão autoral não merece prosperar. Isto porque, embora reconhecida a revelia, a presunção de veracidade não é absoluta.

Ademais, reputar-se-ão verdadeiros os fatos alegados no pedido inicial salvo se o contrário resultar da conviç̧ão do juiz. Contudo, não obstante os fatos alegados pela parte Autora e as provas produzidas, não vislumbro a ocorrência dos danos alegados pela acionante. Os fatos reclamados não possuem o condão de causar à consumidora grave ofensa a sua honra íntima capaz de gerar o direito ao recebimento de indenização por afronta ao direito da personalidade. Nesse panorama, não vislumbro conduta ilícita Ré, não merecendo prosperar o 
pedido de indenização por danos morais, inexistindo violação a direito de personalidade do autor. Aliás, não se podem imputar à Ré qualquer responsabilidade por fato cuja existência não restou devidamente comprovada.

Já foi mencionado no parágrafo acima que, a ré foi considerada revel no presente caso, porém, tal revelia não é absoluta e deve-se analisar o caso em testilha e verificar se de fato a elementos capazes de ensejar uma reparação a título de dano moral, o que não foi evidenciado no caso em comento, segundo se nota no embassamento da decisão do relator.

Não tendo a Autora logrado êxito na comprovação do ato ilícito, não há que se falar em dano, e, muito menos, em direito a indenização. Outrossim, pela descrição fática, não vislumbro o cometimento de dano moral, que não se confunde com o mero aborrecimento ou contratempo, para que este reste caracterizado é necessário que, de forma grave, seja afetada a honra, subjetiva ou objetiva do suposto ofendido, ou sua esfera psíquica tenha sido abalada de forma significativa. Ou seja, pois para se constatar prejuízo indenizável, deverá haver ofensa real e efetiva, daí porque se considera que o mero aborrecimento ou contratempo, embora hábil a gerar certo grau de contrariedade ou amuamento, não se equipara ao dano moral para fins de reparação pecuniária. Entendo, portanto, que não restou caracterizada significativa ofensa à honra ou esfera íntima da parte autora capaz de ensejar pagamento de indenização por dano moral, mas mero contratempo, aborrecimento. Desse modo, constato a impossibilidade de atendimento dos pedidos realizados pelo consumidor, por não vislumbrar a existência de qualquer ato abusivo praticado pela empresa Ré e passível de aplicação das sanções previstas no Código de Defesa do Consumidor (Lei no 8.078/90). Com base no exposto, é forçoso concluir pela improcedência total dos pedidos formulados pela parte autora. Isso posto, JULGO TOTALMENTE IMPROCEDENTE a ação, extinguindo o feito nos termos do art. 487, inciso I, do Código de Processo Civil.¿ Sorteados, coube-me a função de relatar, cujo voto ora apresento com fundamentação sucinta. É breve o relatório. VOTO Requisitos de admissibilidade preenchidos.

A analise do conjunto probatório dos autos, se faz necessário para que não haja a banalização do dano moral, e também serve como um filtro e sedimentação de entendimentos acerca do tema.

Verifica-se que a autora alegou que através do aplicativo Ifood adquiriu esfirras no estabelecimento Habibis, tendo solicitado que as esfirras de carne e frango fossem embaladas separadas das demais, uma vez que continham queijo porque o seu filho menor possui intolerância à lactose, mas a Ré não atendeu o pedido enviando tudo misturado, assim, requereu a restituição do valor pago e indenização por danos morais.

O Réu não se defendeu sendo decretada a sua revelia. A indenização por danos morais existe como forma de reparação a uma situação que atinja o direito da personalidade do postulante, causando-Ihe dor, sofrimento, angústia, ofensa em sua honra, seja objetiva ou subjetiva. No caso dos autos, não se vislumbra ocorrência de ofensa a direito da personalidade e a situação vivenciada não passa de mera chateação. $O$ instituto do dano moral não pode ser banalizado para justificar compensação pecuniária a situações de pouca relevância que fazem parte do dia a dia da vida em sociedade. Quanto ao pedido de restituição do valor pago pelas 4 esfirras, o mesmo também não se justifica, uma vez que 


\title{
A Responsabilidade Civil Frente Aos Aplicativos E-Commerce
}

não é crível que as 48 esfirras não foram consumidas e/ou que seriam consumidas apenas por uma pessoa Assim, aderindo às razões lançadas na sentença, penso que a hipótese é de manutenção desta pelos próprios fundamentos e, para tanto, valho do quanto permitido no artigo 46 da Lei 9.099/95, in verbis: Art. 46. O julgamento em segunda instância constará apenas da ata, com a indicação suficiente do processo, fundamentação sucinta e parte dispositiva. Se a sentença for confirmada pelos próprios fundamentos, a súmula do julgamento servirá de acórdão. Ante o exposto, voto no sentido de CONHECER O PRESENTE RECURSO E NEGAR-LHE PROVIMENTO, mantendo a sentença por seus próprios fundamentos nos termos do artigo 46 da Lei 9.099/95. Custas e honorários advocatícios pelo recorrente vencido, estes últimos arbitrados em $20 \%$ do valor da causa. Acaso beneficiário da justiça gratuita, fica provisoriamente isento nos termos da lei. ALBÊNIO LIMA DA SILVA HONÓRIO Juiz de Direito Relator (TJ-BA - RI: 01607072620208050001 , Relator: ALBENIO LIMA DA SILVA HONORIO, PRIMEIRA TURMA RECURSAL, Data de Publicação: 02/06/2021)

Diante da falta de provas habéis na comprovação do efetivo dano, o recorrente não obteve exito em suas razões de recurso, tendo o recurso sido negado provimento, haja vista que, não se pode banalizar o dano moral, devendo o mesmo ser comprovado através de provas robustas nos autos.

\begin{abstract}
APELAÇÃO - GOLPE DO DELIVERY - DANO MATERIAL E MORAL CARACTERIZADO - MANTUTENÇÃO DA CONDENAÇÃO IMPOSTA NA R. SENTENÇA - Houve evidente falha na prestação de serviço, na medida em que a apelada contratou o serviço de entrega da apelante, confiante que o serviço seria prestado de forma adequada, tendo sido vítima de golpe perpetrado pelo entregador vinculado à apelante, que no momento da entrega exigiu pagamento de taxa de entrega, o que após se tornou conhecido que, em verdade, quantia expressiva havia sido debitada da conta da recorrida. Prestadora de serviço que responde pelos atos praticados pelos entregadores independentemente de vínculo empregatício - Não merece guarida o recurso no que se refere à imputação da ocorrência do evento danoso à conduta da consumidora, ao argumento de que ela não teria agido com cautela, ignorando a mensagem a ela encaminhada acerca da forma de pagamento, já que aos autos não foi colacionada qualquer prova nesse sentido, para que fosse reconhecida, ao menos a culpa concorrente da vítima - Resta evidente o dano moral suportado pela consumidora que teve frustrada a expectativa de realizar com comodidade e segurança compras por meio de aplicativo, em virtude do golpe por ela suportado (débito de valores alheios ao negócio jurídico celebrado em sua conta bancária), conduta essa que fora perpetrada pelo entregador a serviço da própria apelante. RECURSO IMPROVIDO.
\end{abstract}

(TJ-SP - AC: 10538479020208260100 SP 1053847-90.2020.8.26.0100, Relator: Maria Lúcia Pizzotti, Data de Julgamento: 10/02/2021, 30a Câmara de Direito Privado, Data de Publicação: 11/02/2021).

Mais uma vez em Tribunal de São Paulo entende que a responsabilidade civil do aplicativo é objetiva, ou seja, aquela que independe de dolo ou culpa, e mesmo que não exista relação empregatícia entre os entregadores e o aplicativo, o mesmo será responsável por indenizar o consumidor pela fraude do entregador. 
Tribunal de Justiça do Estado da Bahia PODER JUDICIÁRIO PRIMEIRA TURMA RECURSAL - PROJUDI PADRE CASIMIRO QUIROGA, LT. RIO DAS PEDRAS, QD 01, SALVADOR - BA ssa-turmasrecursais@tjba.jus.br - Tel.: 71 3372-7460 RECURSO INOMINADO № 0075358-55.2020.8.05.0001 RECORRENTE: BARBARA DOURADO GONCALVES ADVOGADO: ERIC AINOAN MIRANDA DE ALMEIDA RECORRIDO: RAPPI BRASIL INTERMEDIACAO DE NEGOCIOS LTDA ADVOGADO: GUSTAVO LORENZI DE CASTRO JUÍZO DE ORIGEM: 10ạ VSJE DO CONSUMIDOR DE SALVADOR JUIZ RELATOR: ALBÊNIO LIMA DA SILVA HONORIO EMENTA RECURSO INOMINADO. CONSUMIDOR. VÍCIO DO SERVIÇO. APLICATIVO DE DELIVERY. ALEGAÇÃO AUTORAL DE NÃO ENTREGA DE ALIMENTO ADQUIRIDO ATRAVÉS DE APLICATIVO E NÃO ESTORNO DO VALOR PAGO.

SENTENÇA QUE JULGOU IMPROCEDENTES OS PEDIDOS CONDENANDO A RÉ A RESTITUIR OS VALORES PAGOS PELA COMPRA. RECURSO DA AUTORA, OBJETIVANDO O PAGAMENTO DE INDENIZAÇÃO POR DANO MORAL. VIOLAÇÃO A DIREITO DA PERSONALIDADE. CONFIGURADO. SENTENÇA PARCIALMENTE REFORMADA. RECURSO CONHECIDO E PARCIALMENTE PROVIDO. RELATÓRIO Trata (m-) se de recurso (s) inominado (s) interposto (s) contra a sentença prolatada no processo em epígrafe nos seguintes termos: O cerne da controvérsia posta em exame consiste em saber se houve conduta indevida perpetrada pela rá e se os efeitos daí advindos são aptos a ensejar os pleitos da exordial. In casu, a postulante assevera que vem sofrendo prejuízos por conta dafalha na prestação dos serviços pela acionada, na medida em que, por duas vezes, apesar de ter realizado e pago pelos pedidos de entrega de refeições través do aplicativo da acionada, os itens não foram entregues. Sustenta que, na primeira ocorrência, teria pedido uma pizza, sendo que o entregador da postulada alegou problemas em sua motocicleta para a não realização da entrega.Aponta também que, em 10/05/2020, novamente fora vítima da mesma falha pela acionada conquanto, ao solicitar a entrega de um lanche da McDonalds, no valor total de $\mathrm{R} \$ 56,30$ (cinquenta e seis reais e trinta centavos), incluída taxa de entrega, o prazo previsto para a entrega do item era de 30 minutos, sendo que, após decorrida quase 01 (uma) hora sem o recebimento do produto, entrou em contato coma demandada, através do aplicativo e solicitou o cancelamento da compra e estorno dos valores pagos através do seu catão de crédito. Por fim, alega que, apesar da ré ter dado causa ao cancelamento diante da má prestação dos serviços, não procedeu com o estorno dos valores pagos. No intuito de provar o alegado, a postulante acosta aos autos com a exordial, prints do aplicativo da ré contendo os pedidos e das tratativas de solicitação de cancelamento e estorno. A demandada, por seu turno, contesta a tese autoral, alegando que não houve falha na prestação de seus serviços, tendo a consumidora, por livre escolha, realizado o cancelamento do pedido solicitado em 10/05/2020, objeto da demandada. Argumenta, ainda, que, em que pese não ter dado causa ao cancelamento, procedeu com o estorno dos valores pagos pela autora. Como comprovação do arrazoado, a demandada junta, no bojo da defesa (Evento 15 do PROJUDI), pedaço de imagem constando estorno de valores em cartão de crédito.

No trecho acima, o Tribunal da Bahia faz uma sintese da inicial do autor, aonde o mesmo narra os acontecimentos que esenjara a postulação de sua demanda.

Da análise das provas coligidas nos autos, é inarredável que não há substrato probatório suficiente para o acolhimento da integralidade da pretensão 
autoral, eis que a acionante não trouxe aos autos prova cabal de suas alegações quanto a falha na prestação dos serviços pela acionada. Em que pese a autora afirmar que houve demora demasiada para a entrega do pedido realizado e em 10/05/2020, não traz aos autos qualquer prova que corrobore tal alegação, a exemplo de prints de tela do aplicativo da ré constando o status do pedido. Como sabido, em sede de Juizados Especiais incumbe à parte autora a prova de fato constitutivo de seu direito, conforme preceitua o art. 373. I do CPC. No caso, à luz dos elementos constantes no presente caderno processual, verificase que a parte autora não se desincumbiu do ônus que lhe competia. Nesta linha intelectiva, os argumentos delineados na peça vestibular não restaram suficientemente comprovados. Trata-se de matéria fática que necessita de provas robustas acerca do suposto evento danoso. Conforme se depreende do alicerce fático e documental, constante nos presentes autos, resta inarredável considerar a ausência de ato ilícito da ré que viabilize a medida reparatória almejada. Assim, não há de se falar em responsabilidade civil por ausência do requisito elementar para tanto.

De outra banda, tendo a ré confirmado que procedeu com o estorno dos valores à autora, chamou para si o ônus da prova. Neste diapasão, a imagem juntada no bojo da peça contestatória, por si só, não prova suficiente para demonstrar a efetiva realização do estorno, até mesmo porque, da análise da referida imagem não há indicação da titularidade do cartão de crédito ali constante. Ante o exposto, considerando as razões supracitadas e por tudo que dos autos consta, julgo PROCEDENTE EM PARTE OS PEDIDOS DA EXORDIAL, para condenar a ré a restitui a autora, na forma simples, o valor de $\mathrm{R} \$ 56,30$ (cinquenta e seis reais e trinta centavos), acrescidos de juros de $1 \%$ ao mês a partir da citação e correção monetária pelo INPC a partir do evento danoso, ou seja, 10/05/2020.

O ônus da prova é de quem alega, devendo então o autor trazer provas habeis para comprovar o direito ora pleiteado.

Julgo IMPROCEDENTES os demais pedidos da exordial. Não havendo recursos, arquivem-se os autos, observando o prazo legal Sorteados, coube-me a função de relatar, cujo voto ora apresento com fundamentação sucinta. É breve o relatório. VOTO Requisitos de admissibilidade preenchidos. No mérito, a sentença hostilizada deve ser parcialmente confirmada, nos termos do art. 46 da Lei no 9.099/95, servindo de acórdão a súmula do julgamento, comportando reforma apenas no ponto atinente à indenização por danos morais Restou comprovada a não entrega do produto adquirido pela parte autora conforme bem pontuado pelo juízo sentenciante. Assim, havendo falha na prestação de serviço nasce o dever de reparar. Por tais motivos, penso que, está configurado e provado os danos morais alegados pela Autora e voto no sentido de dar provimento ao recurso do consumidor. A compensação por danos morais, deve ser apta ao cumprimento de um duplo papel, qual seja reparatório e punitivopedagógico, devendo a fixação dos danos morais observar a extensão do dano ocasionado, o potencial econômico do agente causador da lesão, além da observância aos princípios da proporcionalidade e da razoabilidade. Em relação ao quantum indenizatório, levando-se em consideração os fatos narrados e o comportamento das Rés, penso que o valor de $R \$ 2.000,00$, está adequado e atende os critérios acima mencionados. Ressalte-se que esse tem sido o entendimento adotado na 1 a Turma Recursal, conforme julgado abaixo: 
Tribunal de Justiça do Estado da Bahia PODER JUDICIÁRIO PRIMEIRA TURMA RECURSAL - PROJUDI PADRE CASIMIRO QUIROGA, LT. RIO DAS PEDRAS, QD 01, SALVADOR - BA ssa-turmasrecursais@tjba.jus.br - Tel.: 71 33727460 1a TURMA RECURSAL CIVEL E CRIMINAL PROCESSO №. 004586703.2020.8.05.0001 RECORRENTE: RAIR VALENTE SOARES RECORRIDA: RAPPI BRASIL INTERMEDIACAO DE NEGOCIOS LTDA RELATORA: JUÍZA SANDRA SOUSA DO NASCIMENTO MORENO EMENTA RECURSO INOMINADO. AÇÃO INDENIZATÓRIA. RELAÇÃO DE CONSUMO. TENTATIVA DE COMPRA FRUSTRADA. COMPRA QUE FOI CANCELADA SEM QUALQUER MOTIVO PLAUSÍVEL.PARTE AUTORA ALEGA NUNCA TER RECEBIDO O PRODUTO COMPRADO. VALOR PAGO NÃO DEVOLVIDO. DANOS MORAIS CONFIGURADOS E COMPATÍVEIS COM O ENTENDIMENTO DA TURMA. SENTENÇA MANTIDA. RECURSO NÃO PROVIDO. RELATÓRIO Insurge-se o demandante contra a sentença julgou parcialmente procedente a ação para: Destarte, à vista do exposto, JULGO PROCEDENTES EM PARTE, para condenar a Ré a proceder com a devolução do valor de $\mathrm{R} \$ 230,00$ (duzentos e trinta reais), atualizada do desembolso e com juros da citação; bem como indenizar moralmente o Autor no valor de $\mathrm{R} \$ 2.000,00$ (dois mil reais), acrescido de juros de mora e correção monetária a partir desta decisão, conforme Súmula 362 do STJ. Intimada, a recorrida apresentou contrarrazões (ev. 43). VOTO Presentes as condições de admissibilidade do recurso, consoante dispõe o artigo 42 e parágrafo 1 으 da Lei 9099/95, requerida a justiça gratuita, conheço do mesmo. Adentrando na análise do mérito recursal, entendo que o mesmo não deve ser provido. Alega a parte autora que em 01/10/2019 teria inserido o valor de $\mathrm{R} \$ 230,00$ (duzentos e trinta reais) na plataforma da ré para realizar a compra de remédio contraceptivo (Diafragma). Afirma que, em 04/10/2019, teria entrado em contato com o estabelecimento que fornecia o produto, reservando-o para que entregador da ré pudesse retirá-lo. No entanto, seu pedido teria sido cancelado sem motivo aparente. Aduz ainda que repetiu o mesmo procedimento por mais 3 (três) vezes, entretanto, em nenhuma ocasião teve seu pedido retirado e entregue, vindo a ser automaticamente cancelado. Em razão do exposto pleiteia a restituição do valor desembolsado, bem como indenização por danos morais. A ré aduz inocorrência de conduta ilícita e, por conseguinte, de danos morais. O Juízo a quo concluiu que pela procedência parcial da ação.

No trecho abaixo, é novamente exposto pelos Tribunais Pátrios que a responsabilidade civil dos aplicativos é objetiva, pois, não se faz necessário comprovar se houve culpa da prestadora de serviço.

Verifico que houve o descumprimento na entrega e os elementos constantes dos autos são suficientes para autorizar a condenação da ré ao pagamento de danos morais. Segundo o art. 14, § 3으. II, do CDC, o fornecedor do produto ou o prestador do serviço responde, independentemente da existência de culpa, pelos defeitos na prestação do serviço, somente se desonerando da obrigação de indenizar se demonstrar a inexistência do defeito na prestação do serviço, ou provar a culpa exclusiva do consumidor ou de terceiro, o que não ocorreu no caso em tela. Aquele que lucra com o negócio não pode se furtar à responsabilização pelo prejuízo, deixando o consumidor prejudicado sem qualquer proteção. Nesses casos, o dano moral existe e independe de prova de culpa do demandado, dada a responsabilidade objetiva, em decorrência do risco do empreendimento, considerando a caracterização do dano moral. Quanto ao valor fixado na sentença, importância de $\mathrm{R} \$ 2.000,00$ (dois mil reais), embora seja difícil quantificar o dano moral, predomina o entendimento que 
deve ser fixado observando-se o princípio da razoabilidade e proporcionalidade, entretanto, não pode ser um valor irrisório posto que descaracterizaria o caráter intimidatório da condenação. Assim, a sentença impugnada não merece reparos, pois, levando-se em consideração a qualidade das partes envolvidas, valores aplicados por essa Turma para casos semelhantes, bem como transtornos suportados pela parte, o valor arbitrado é adequado à reparação do dano. Com essas considerações, e por tudo mais constante dos autos, voto no sentido de NEGAR PROVIMENTO ao recurso, mantendo-se a sentença em todos os seus termos, vide o art. 46 da Lei 9.099/95. Condenação em custas e honorários advocatícios arbitrados em $20 \%$ (vinte por cento) sobre o valor da condenação, restando suspensa a exigibilidade do pagamento pela parte autora, pelo prazo de 05 (cinco) anos, nos termos do art. 98, § 3ㅇ, do CPC/2015 Salvador, 15 de janeiro de 2021. Sandra Sousa do Nascimento Moreno JUÍZA RELATORA (Classe: Recurso Inominado, Número do Processo: 0045867- 03.2020.8.05.0001, Relator (a): SANDRA SOUSA DO NASCIMENTO MORENO, Publicado em: 25/02/2021). Ante o exposto, voto no sentido de CONHECER O RECURSO E DAR-LHE PARCIAL PROVIMENTO, para condenar a Ré ao pagamento de indenização por danos morais no valor de $R \$ 2.000,00$ (dois mil reais), valor esse que deverá ser devidamente atualizado na forma da Súmula 362 do STJ, e acrescido de juros de mora a partir da citação. Sem custas nem honorários, ante o resultado. ALBÊNIO LIMA DA SILVA HONÓRIO Juiz de Direito Relator (TJ-BA - RI: 00753585520208050001, Relator: ALBENIO LIMA DA SILVA HONORIO, PRIMEIRA TURMA RECURSAL, Data de Publicação: 11/06/2021).

O Relator do recurso trazido no julgado acima, entendeu que as provas constantes no processo, foram suficientes na comprovação da falha de prestação de serviço por parte da recorrida, diante disso, deu parcial provimento no recurso interposto pelo recorrente e modificou a sentença proferida pelo Juiz de piso, que não entendeu haver provas habéis capazes de comprovar o dano sofrido pelo autor.

Restou evidente nos julgamentos dos Tribunais colacionados em linhas pretéritas que, faz-se necessário moldação do Código Civil e o Código de Defesa em cada caso concreto, para que se chegue em uma decisão equânime, trazendo a devida segurança jurídica e evitando a banalização do dano moral.

\section{CONSIDERAÇÕES FINAIS}

A presente pesquisa tratou sobre a responsabilidade civil dos prestadores de serviços no âmbito do direito do consumidor, apontando os requisitos necessários e a legislação aplicável. Tal tema nos dias atuais possuem grande importância diante da grande demanda processual envolvendo os casos em que se aplica a responsabilidade civil no direito consumerista brasileiro. Inicialmente, verificou-se a evolução histórica da responsabilidade civil e o momento em que esta começou a ser aplicada dentro do ordenamento jurídico brasileiro. 


\section{A Responsabilidade Civil Frente Aos Aplicativos E-Commerce}

Observou-se que a responsabilidade civil surgiu num primeiro momento no direito francês, pois anterior à ele não havia distinção entre a responsabilidade civil e a responsabilidade penal, as quais também são abordadas dentro da evolução histórica, pois foi necessária sua distinção para chegar ao conceito e à aplicação atual da responsabilidade civil em vários ordenamentos jurídicos.

No decorrer informativo se aborda de forma mais específica o objetivo do presente trabalho, que foi o de explicar como ocorre a responsabilidade civil no direito do consumidor, os aspectos gerais do direito consumerista, apontando, por fim, a responsabilidade civil do prestador de serviços, conforme a doutrina e a jurisprudência dos doutrinadores brasileiros e do Tribunal de Justiça.

Portanto aufere-se que, tanto Decreto 7.962 quanto o $\mathrm{MCl}$, aliados à Constituição Federal e ao Código de Defesa do Consumidor, vigem para complementar a proteção do polo vulnerável das relações consumeristas do comercio eletrônico. $\mathrm{O}$ dispositivo em questão busca equilibrar a vulnerabilidade do consumidor virtual frente as incertezas advindas das compras online, tendo se preocupado com a necessidade dos sites eletrônicos deixarem claras as informações para o consumidor. Todavia, o consumidor encontrou grandes problemas ao buscar identificar quem responsabilizar na hipótese do produto apresentar falhas, ou este nem chegar ao seu destino e nos casos dos serviços não corresponderem com as expectativas que dele se esperavam.

Destarte, devido ao avanço tecnológico das relações de consumo, o presente trabalho visou elucidar jurisprudencialmente como se posicionam os tribunais quando a empresa apenas faz o papel de intermediadora atuante, aproximando dois consumidores e transformando um deles em uma espécie de fornecedor. Ressalto que a doutrina preceitua que CDC é plenamente aplicável no e-commerce, desde que o mediador tutele a entrega, o pagamento, ou gerencie as negociações. Outra consideração a ser feita é que os contratos realizados pelo dispositivo eletrônico não são uma nova fonte de obrigações, mas sim um meio inovador pelo qual o consumidor pode se relacionar e concretizar transações com outros fornecedores ou até mesmo outros consumidores.

Menciona-se ainda que o Código de Defesa do Consumidor não visa cuidar de apenas um tipo de contrato em específico, tendo como preceito básico proteger o consumidor em todas as relações de consumo, seja elas envolvendo um fornecedor tradicional ou um intermediário. Na esteira do dito, os tribunais brasileiros posicionam-se em consonância com a doutrina, pontuando que os fornecedores intermediários de relações de consumo interpessoais concretizadas no comércio eletrônico respondem objetiva e solidariamente, posto que lucram economicamente pelos negócios concretizados entre consumidores e terceiros. 


\section{A Responsabilidade Civil Frente Aos Aplicativos E-Commerce}

Diante do exposto, respondendo à hipótese que conduziu esta pesquisa, urge-se que por não haver uma legislação específica para tratar das modernas relações virtuais advindas do comércio eletrônico, ante o assombroso crescimento da tecnologia e do avanço da internet, o Código de Defesa do Consumidor, dadas as sólidas decisões judiciais recentes, deve efetivamente ser aplicado quando a negociação for interpessoal (Consumer-to-Consumer) e amparada por um fornecedor que atue diretamente na transação, seja no pagamento, na oferta, ou até mesmo na entrega, atribuindo responsabilidade objetiva e solidária aos fornecedores intermediários, com o objetivo de proteger o polo vulnerável e tornando as transações digitais mais seguras e confiáveis.

Assim, o Direito, instrumento que normatiza a sociedade, deve acompanhar as mudanças tecnológicas e o perfil do consumo da população para que esteja preparado para as necessidades da sociedade atual no âmbito jurídico. Verificou-se que há um entendimento majoritário entre os doutrinadores e o entendimento jurisprudencial, reconhecendo que o direito do consumidor é aplicado em quaisquer contratos de prestação de serviços.

Por fim, observou-se que a responsabilidade civil do prestador de serviços ocorre sempre que houver um ato ilícito e um dano causado ao consumidor, devendo haver o nexo de causalidade entre estes, para que ocorra o dever de indenizar. No entanto, ela pode ser afastada em razão da incidência de uma das excludentes de responsabilidade, não ocorrendo o dever de indenizar por parte do prestador de serviços ou fornecedor de produtos, nos termos do Código Civil e do Código de Defesa do Consumidor.

Com isso, a partir do presente trabalho, é importante ressaltar a necessidade de uma regulamentação voltada para o meio virtual, pois o comércio virtual não altera a figura de consumidor e fornecedor apesar destes serem modernamente chamados de e-consumer e e- seller - pois se altera tão somente o meio e a forma da contratação, deixando intactas as figuras das partes envolvidas, tornando aplicável, apesar de não em sua total efetividade, o Código de Defesa do Consumidor. 


\section{A Responsabilidade Civil Frente Aos Aplicativos E-Commerce}

\section{REFERÊNCIAS}

BARROS, João Pedro Leite, Os contratos de consumo celebrados pela internet: Um estudo de Direito Comparado Luso-Brasileiro, Editora AAFDL, Estudos de Direito do Consumo, v. V, Lisboa 2017. p. 503.

BONATTO, Cláudio. Código de defesa do consumidor: cláusulas abusivas nas relações contratuais de consumo. 2. ed. rev. atual. Porto Alegre: Livraria do Advogado, 2004, p. 19.

BRASIL. Código de Defesa do Consumidor (Lei no 8.078). Disponível em:

http://www.planalto.gov.br/ccivil_03/Leis/L8078.htML

FINKELSTEIN. Maria Eugenia Reis. Direito do comércio eletrônico. 2. ed. Rio de Janeiro: Elsevier, 2011, p. 175.

FRANÇA, G. V. (2017). Direito Médico (14a. ed. ed.). Rio de Janeiro: Forence.

GAGLIANO, Pablo Stolze; FILHO, Rodolfo Pamplona. Manual de Direito Civil: volume único. São Paulo:Saraiva Jur.,2017. p. 865. Disponível em:

https://direitoemsala.files.wordpress.com/2017/08/manual-de-direito-civil-pablo-stolze- 2017.pdf.

GREENBERG, Andy. It's Been 20 Years since This Man Declared Cyberspace Independence. Wired. Disponível em: https://www.wired/

LAWAND, Jorge Jose. Teoria Geral dos Contratos Eletrônicos. São Paulo: Juarez de Oliveira. 2003.

MARQUES, Claudia Lima. Comentários ao código de defesa do consumidor. São Paulo: RT, 2003, p. 95.

MARQUES, Claudia Lima; Contratos no Código de Defesa do Consumidor: o novo regime das relações contratuais. 5. ed. rev., atual. e ampl. São Paulo: Editora Revista dos Tribunais, 2005.p. 71

MARTINS, Ives Gandra; REZEK, Francisco. Constituição Federal. Avanços, contribuições e modificações no processo democrático brasileiro. São Paulo: RT, 2008.

MATIELO, F. Z. (2014). Responsabilidade civil do médico (4a. ed. ed.). São Paulo, Brasil: LTr

MIRAGEM, Bruno. Curso de Direito do Consumidor I. - 6. ed. São Paulo: Editora Revista dos Tribunais, 2016. p. 549.

NEVES, Thiago Ferreira Cardoso. O Comércio Eletrônico e o Direito do Consumidor. R. EMERJ, Rio de Janeiro, v. 17, n. 64, p. 154- 163, jan. - abr. 2014. Disponível em: https://core.ac.uk/reader/79118290

PINHEIRO, Patrícia Peck. Direito Digital. São Paulo: Saraiva, 2016.

SALGARELLI, Kelly Cristina. Direito do consumidor no comércio eletrônico: uma abordagem sobre a confiança e a boa-fé. São Paulo: Ícone, 2010, p. 79.

SANTOS, João Victor Livramento dos. COMÉRCIO ELETRÔNICO: A responsabilidade civil dos sites intermediadores de compra. Brasília, 2019. Disponível em?

https://bdm.unb.br/bitstream/10483/25246/1/2019_JoaoVictorLivramentoDosSantos_tcc.pdf

VENOSA, Sílvio de Salvo. Direito Civil: Obrigações e Responsabilidade Civil. 17. ed. São Paulo: Atlas, 2017. p. 390. 